\title{
PREFACE TO \\ THE SECOND ENGLISH-LANGUAGE EDITION OF THE MASTERS AND THE SLAVES
}

$\mathrm{R}$ ATHER than preserve here all the prefaces written for the several Portuguese editions of Casa-Grande \& Senzala, I have decided to keep only the Preface written especially for the First English-Language Edition, and to fuse the others into this single synthetic Preface.

Accomplishing this was not easy. Prefaces for new editions, now as always being written by the calendar, I faced a problem of time. Also, there was something journalistic about the Portuguese Prefaces which makes them valuable only in relation to their dates. Nevertheless, some of the tentative ideas set forth in a preface may have both a chronological time-value and a psychological value in relation to a book that does not die in its first, second, or third edition. Such ideas and their possible psychological time-values are the ones I have included in this synthetic Preface. In doing this I have tried to fuse the several Portuguese Prefaces in the light of Dr. Johnson's generalization: "In contemplation we easily contract the time of real actions, and therefore willingly permit it to be contracted when we only see their imitation."

When I wrote the long Preface to the First Portuguese-Language Edition of my first long essay on the patriarchal society of Brazilfrom the days when Brazil was a colony of the king of Portugal to the first period of the equally patriarchal and almost equally colonial national monarchy-and when I wrote the long Preface to the Second Portuguese-Language Edition, I was performing a sort of pioneering work which necessitated justification of some of my unorthodox methods. Those methods were somewhat more scandalous to some academic minds then than they are today-in fact, they were almost pure heresy.

Now that in the English-speaking world a writer like Mr. David Riesman has won recognition for books that (according to a favorable criticism of them) "cut across the social sciences," here picking a method of treatment from anthropology and using it to handle history, there mingling ideas from psychoanalysis and economics and "enriching the result"-as a critic has pointed out-"with literary references" (from Tolstoy, Samuel Butler, Virginia Woolf, Franz Kafka, St. Augustine, Nietzsche, Cervantes, Joyce, etc.) and, besides this, presenting himself "relatively free of academic jargon," it is no xviii 


\section{Preface to the Second English-Language Edition xix}

longer shocking for a Brazilian author to have done precisely that years before The Lonely Crowd was published.

Remembering some of the sharp or sarcastic remarks of strictly academic critics (English-speaking and Brazilian) about my pioneering work, I can now neutralize their poison-for they meant to kill what they considered to be an absurd book - with the generous understanding that I have met more recently not only in Europe (especially France), but also in the two Americas. This generous understanding has been coming more and more from such orthodox or conservative academic centers as the Sorbonne, the University of Strasbourg, Heidelberg, Rome, Coimbra, and -in the United States-such universities as Virginia, Princeton, Harvard, Northwestern, and Columbia. It was at Columbia, years ago, that I did graduate work with a scholar who was one of the first to think my experimental work not entirely worthless: Franz Boas. Another who found some worth in my scandalous book soon after its appearance was Señor José Ortega y Gasset; a third was the Swiss anthropologist Alfred Métraux.

Another significant change tending to prove that time has much to do with the fate of books has occurred in the attitude of some of the conservative groups that at first, through a few of their most representative voices, considered the present book hostile to them-some of the Jesuits, for example, and some Jewish leaders who went so far as to see "anti-Semitism" in my book. Now a better understanding is evident in both groups. Etudes, the well-known publication of the Paris Jesuits, regretted-in a book review published in 1952 -that this book had not been translated sooner into French. Some outstanding Jewish leaders in Europe, the United States, and Latin America have publicly acknowledged my work as an endeavor to do justice to the Jewish contribution to Iberian civilization. In recent years also, the Communists, who at first took the attitude that this book was written from an "unprogressive" point of view, being too nostalgic over a past that should be repudiated by those who believe in "social progress," have become more tolerant of my ideas and my methods.

The fact is, of course, that I never meant to be anti-Jesuit or antiSemitic. I admire the Jesuits, and I have always pointed out that Iberian and Ibero-American populations and cultures owe much to both Jewish and Moorish elements and values. Nor did I intend to oppose to "progressive" Communism, of Russian or some other style, a systematic or sentimental apology for the Luso-Brazilian "feudalistic" past. What I wanted to save from conventionally narrow points of view was a number of such Luso-Brazilian achievements as miscegenation and the fusion of cultural values which pseudosocial scien- 
tists like Gustave Le Bon have represented as absolutely disgraceful or harmful to so-called human progress. Those achievements are now being seen by other, technically more progressive peoples as culturally and politically valuable anticipations of what some modern thinkers, social anthropologists, and statesmen now consider to be adequate European behavior in tropical areas, areas in which European civilization enters into close relations with a non-European physical milieu and non-European races and cultures.

Thanks to my English-language publisher, Mr. Alfred A. Knopf, this book reappears in English not as a mere expression of a Latin American writer endeavoring to consider a Latin American situation through purely Latin American eyes, but as of possible human interest exceeding and transcending its regional significance and regional material. It was thus treated by European critics when presented in the French translation published by Gallimard in Paris-an edition which, appearing in 1952, has already been reprinted seven times. A French critic said that a book can be at once regional and universal in the perspective it tries to open up, in a pioneering way, with regard to primarily human matters needing to be considered whenever possible as human wholes or complexes within their regional configurations (in this case a Latin American configuration). Such wholes or complexes should not be sacrificed entirely to the treatment generally given them by rigid specialists in one or another branch of the social sciences, social history, or human geography, a treatment tending to deal with them as dry, dead fragments of wholes that on being dealt with in this anatomical way immediately cease to be living realities.

As I said above, since the first publication of this book in Portuguese in Rio de Janeiro in December 1933, books with this inter-related, integrative point of view have appeared in the United States and have been well treated even by academic critics. But in 1933 a book of this adventurous, experimental sort was considered to be violently opposed to the dominant academic orthodoxy in the United States and other countries. For excessive academic specialization had perverted social studies with extremes of pedantic purity. Aiming to separate such studies entirely from literature and other humanities, such specialization succeeded only in making most social studies caricatures of the biological or physical sciences.

Changes in attitude in the relations between social sciences and the humanities have been such in the United States and Europe during the past decade that university teachers of sociology, psychology, and other social sciences frankly admit that the social problems confronting the modern world challenge everyone to seek greater social in- 


\section{Preface to the Second English-Language Edition xxi}

sight. They admit that awareness and understanding of human values and relationships may be increased in students of social subjects if to the purely scientific analysis of these subjects are added other approaches, including disciplines from history, literature, philosophy, the humanities. This explains the publication in English for the use of students of social sciences-particularly of social anthropology-of books in which short stories and novels are employed to increase that awareness and that understanding. This interrelationistic or-as some would prefer to call it-integrative point of view dominates the area studies that have been introduced in a number of Anglo-American universities since the Second World War. Those studies have had valuable consequences for the study of social and cultural problems as regional wholes or complexes. The value of literary and folkloric approaches should not be disregarded or thought unworthy of contributing, alongside scientific analysis of their inter-relationships, to a deeper, more comprehensive interpretation of such regional complexes.

In writing on the patriarchal society of Brazil an essay that was also an attempt to analyze and interpret the meeting in a tropical area of a European civilization and at least two primitive cultures, as well as other non-European influences such as those brought to Brazil from the Orient by the Portuguese, I was trying to accomplish a pale equivalent of what Picasso has masterfully accomplished in plastic art: the merging of the analytic and the organic approaches to man: what one of his critics has called "a creative image." By doing that, the same critic said, Picasso promoted the intrusion of scientific dissection into art, thus showing by his action an accord with some aspects of modern science. But in this attempt to define the organic bases of form in all their possible virgin condition-through intuitive as well as concrete study of the Negro and the Polynesian-Picasso linked himself with the rebellion against some aspects of modern academic science. His aim, however, having been to express new potentialities of integration that might resolve contradictions, his pioneering work may be considered an example (as some of his critics have pointed out) of the way by which the union of images, ideas, and forms drawn partly from science and partly from anthropological material artistically apprehended may become an expression of what one of these penetrating critics, the Englishman J. Lindsay, considers "the unitary trend which is emerging in all really creative work of our period. . . ."

For, as Mr. Lindsay points out in his very intelligent pages on the present status of anthropology in relation to art, only a unitary methodology in anthropological studies "can make the whole human tradi- 
tion a vital part of common experience," thus overcoming "the deadening and disintegrative forces of an industrialism based on mechanist science," disintegrative forces that have radically separated technically successful types of culture from the subdued or technically dominated ones, breaking the unity of man into at least two antagonistic types. The truth really seems to be that only "within" the living whole of human development can the relations between what is arbitrarily considered rationality and irrationality in human behavior, or between different human cultures, be fully understood. Consequently, one is justified in associating anthropology with history, folklore with literature, when one has to deal, as in the case of Brazil, with a human development in which "rational" and "irrational," "civilized" and "primitive" elements have mingled intimately, all contributing to the process of adaptation to life in a tropical and quasi-tropical area of a new type of society and a new harmony among otherwise antagonistic men-white and black, European and brown, civilized and primitive.

In attempting to do this, I was reminded more than once of the words of Henry James concerning the novel as vital literature. The novel to him was indeed "a living thing, all one and continuous ... in each of the parts there is something of each of the other parts."

Of a history like the one outlined in this book-part history, part anthropology, part genetic or psychological sociology-with timevalues that are also modified by differences of approach - the anthropological and the historical-I might say that, within modest limits, it was history attempted also as "a living thing, all one and continuous . .." with something from one past always present in the other pasts. My aim has been to reach what Mr. Lindsay calls "a creative image." Hence the literary character of this anthropological-historical essay, which has been pointed out by some of the ablest French, Italian, German, and British critics in their generous comments, and irrespective of their "Existentialist" or "Sartrist" views of literature and of their Roman Catholic or Marxist or post-Marxist ideology. This literary character, not sacrificing its possible scientific structure-a structure maintained by a combination of several scientific approaches -was most clearly pointed out in Le Figaro Littéraire, by M. André Rousseaux, and by the critic of The Economist (London).

Some writers have compared the "creative image" aimed at in this essay, as it tries to fuse the historical and anthropological past and their mixture with the present, with the Proustian technique of recapturing the past. In both cases there is a study of human figures and social situations in which the apprehension of those realities by the scientific observer's eyes, as space-forms, is completed by the appre- 


\section{Preface to the Second English-Language Edition xxiii}

hension of the same realities by the observer's participant mind, as time-formations. This technique is illustrated by Proust's conception of the Duchesse de Guermantes as "a collective name . . . not merely in history, by the accumulation of all the women who have successively borne it, but also in the course of my own short life, which has already seen, in this single Duchesse de Guermantes, so many different women superimpose themselves, each one vanishing as soon as the next has acquired sufficient consistency."

In writing this book, which deals also with barons and baronesses, with captains and captains' wives from the colonial and imperial days of Brazil-men and women whose names were also collective, and whose succession in Brazilian life also was sociological as well as historical, in the sense that some of them were always masters in relation to slaves-I did indeed try to follow them as time-formations and, at the same time, as regional space-forms. I have tried to do this from a historical-sociological or historical-anthropological point of view, perhaps aided in some instances by a literary intrusion of my own person as participating in a social and psychological present still pregnant with the past, a historical past mainly European, and an anthropological past mainly Amerindian and African. The latter was represented by the influence of native women upon conquerors somewhat lost in the tropical wilderness, of slaves upon the minds, culture, and sometimes the bodies of the masters.

A modern Anglo-American sociologist has written that where Freud abstracts the libido, sociologists might abstract status. In relation to the Brazilian past, as in relation to other national and regional pasts, perhaps both libido and status should be abstracted. The sociological treatment of history should be supplemented with a psychological treatment. To do that was my aim in this book.

It is now generally admitted by anthropologists and sociologists that social science has become less intolerant than it was twenty years ago of what was then considered subjective psychology. Recesses of the mind-individual and collective, present and past - not to be visited easily by objective sociologists or anthropologists are now admitted to exist by an increasing number of students of human behavior and the human past, some of whom recognize the possibility of exploring those recesses by not entirely objective techniques and methods.

Now a few words as to how this essay was conceived and written, how it developed into an unorthodox book under both academic and extra-academic influences that led me to a new and adventurous treatment of a complex subject. 
In October 1930 I embarked upon the adventure of exile, going to Bahia and Portugal, with Africa as a port of call-the ideal journey for the studious interests reflected in this book. I was secretary to the governor of Pernambuco when the 1930 revolution broke out there with un-Brazilian violence. People died on both sides, and seventeen residences were burned in the city of Recife, that of my own family included. Although non-partisan, I suffered the effects of partisan violence and, to my surprise and that of others, became a political émigré in Portugal, the United States, and Germany.

While in Portugal I unexpectedly received, in February I93 I, an invitation from Stanford University to be one of its visiting professors in the spring of that year. With nostalgic regret I left Lisbon, where this time, in the course of a few months of leisure, I had been able to familiarize myself with the National Library, with the collections in the Ethnological Museum, with novel vintages of port, and with new varieties of codfish and sweetmeats. Added to this had been the pleasure of viewing Cintra and the Estories once again and of greeting distinguished acquaintances, among them the admirable scholar João Lúcio de Azevedo.

A similar opportunity had been mine in Bahia-known to me of old, but only from brief visits. Residing in Salvador, I could take my time in becoming acquainted not only with the collections in the Nina Rodrigues Museum of Afro-Bahian antiquities, with the art of apparel of the Negro women confectionery workers, and that art which they employ in the decoration of their cakes and cake-trays, ${ }^{1}$ but also with certain more intimate delights of the Bahian kitchen and sweetmeat shop that escape the observation of the ordinary tourist, representing the more refined culinary tastes of the old Big House that have found in the hearths and cake-boards of Bahia their last stronghold and, God grant, an invincible one. I here must express my thanks to the Calmon, Freire de Carvalho, and Costa Pinto families, as well as to Professor Bernadino de Sousa of the Historical Institute, to Brother Philotheu, superior of the Franciscan Monastery, and to the Negro woman Maria Inácia, who provided me with interesting data on the dress of the Bahian women and the decoration of sweetmeattrays. "Une cuisine et une politesse! Oui, les deux signes de vieille

1 A separate study might well be made of the decorative and possibly mystical motives employed by these women in Bahia, in Pernambuco, and in Rio de Janeiro in the cutting of paper-blue, carnation-colored, yellow, etc.-for the garnishing of their trays and the packing of the sweets, and the forms that they give to their cakes, sugar-pastes, sugar-plums, and the like. The decoration of the trays is a true art of lacework in the medium of paper, executed practically without a pattern. 


\section{Preface to the Second English-Language Edition $\mathrm{xxv}$}

civilisation," I recall having learned in a French book. And that is precisely what I remember best about Bahia: its courtesy and its cooking, two expressions of patriarchal civilization that today are to be met with there as in no other part of Brazil. It was Bahia that gave us some of our major statesmen and diplomats under the Empire; and similarly in no other region are the most savory dishes of the Brazilian cuisine prepared so well as in the old houses of Salvador and the Reconcavo. ${ }^{2}$

Having given the courses that, on the suggestion of Professor Percy Alvin Martin, had been entrusted to me at Stanford University-one a course of lectures, the other a seminar, courses that brought me into contact with a group of young men and women students animated by a lively intellectual curiosity-I returned from California to New York by a route new to me: across Arizona, New Mexico, and Texas, an entire region that, in its wildest stretches, reminds one who comes from northern Brazil of our own backlands or Sertão, bristling with mandacarús and xique-xiques. ${ }^{3}$ Desert wastes in which the vegetation has the appearance of enormous bottlenecks, of a crude and at times sinister green in color, thrust down into the arid sand.

No sooner has one crossed the New Mexico state line, however, than one begins to lose the feeling of a Brazilian backlands paysage, the place of which is now taken by the landscape of the old slave-holding South. This impression reaches a peak as the transcontinental express enters the canebrakes and swamps of Louisiana. Louisiana, Alabama, Mississippi, the Carolinas, Virginia-the so-called "deep South," a region where a patriarchal economy created almost the same type of aristocrat and of Big House, almost the same type of slave and of slave quarters, as in the north of Brazil and in certain portions of our own south; the same taste for the settee, the rocking-chair, good cooking, women, horses, and gambling; a region that has suffered and preserved the scars (when they are not open and still bleeding wounds) of the same devastating regime of agrarian exploitation: fire and ax, the felling of the forests and the burning over of the land, the "parasitic husbandry of nature," as Monteiro Baena puts it with

2 The Reconcavo is a strip of land outside the city of Salvador (Bahia), bordering All Saints Bay. It is some sixty miles long and varies in breadth up to thirty miles. It was formerly the seat of the landowning and slave-holding rural aristocracy. (Translator.)

8 The mandacarú is a variety of fig tree, this being the vernacular name in Brazil for a species of Cereus in general. Euclides da Cunha (Os Sertões, 16th edition, p. 43) identifies it as the Cereus jaramacaru. The xiquexique, also spelled chique-chique, is identified by Cunha (ibid.) as the Cactus peruvianus; it would appear to be the Opuntia brasiliensis, or the Opuntia in general. (Translator.) 


\section{xxvi The Masters and the Slaves}

reference to Brazil.4 Every student of the patriarchal regime and the economy of slave-holding Brazil ought to become acquainted with the "deep South." The same influences deriving from the technique of production and of labor-that is to say, the one-crop system and slavery-have combined here in this English-settled portion of North America, as in the Antilles and Jamaica, to produce social results similar to those that are to be observed in our country. At times, indeed, they are so similar that the only variants to be found are in the accessory features: the differences of language, race, and forms of religion.

I had the good fortune to make the greater part of this journey through the Southern states of the Union in the company of two former colleagues of Columbia University, Ruediger Bilden and Francis Butler Simkins. The former was specializing, with all the rigorous detachment of his Germanic cultural background, in the study of slavery in the Americas, particularly in Brazil. The latter was engaged in studying the effects of abolition in the Carolinas, a subject on which he has since written a most interesting book in collaboration with Robert Hilliard Woody: Soutb Carolina during Reconstruction (Chapel Hill, 1932). To these two friends, and especially to Ruediger Bilden, I am indebted for valuable suggestions in connection with the present work; and to these names I should add that of another colleague, Ernest Weaver, the companion of my studies in anthropology in the course given by Professor Franz Boas.

The scholarly figure of Professor Boas is the one that to this day makes the deepest impression upon me. I became acquainted with him when I first went to Columbia. I do not believe that any Russian student among the romantics of the nineteenth century was more intensely preoccupied with the destiny of Russia than was I with that of Brazil at the time that I knew Boas. It was as if everything was dependent upon me and those of my generation, upon the manner in which we succeeded in solving age-old questions. ${ }^{5}$ And of all the problems confronting Brazil there was none that gave me so much anxiety as that of miscegenation. Once upon a time, after three straight years of absence from my country, I caught sight of a group of Brazilian seamen-mulattoes and cafusos-crossing Brooklyn

4 Antônio Ladislau Monteiro Baena: Ensaio chorográpbico sobre a província do Pará (Chorograpbic Essay on the Province of Pará) (Pará, 1839).

5 Freyre has given an admirable picture of his generation in his book Regiäo e tradição (Region and Tradi- tion) (Rio de Janeiro, 194r). See especially his paper: "Apologia pro generatione sua," in which he has some extremely interesting things to say about Randolph Bourne as well as Charles Péguy and Ernest Psichari. (Translator.) 


\section{Preface to the Second English-Language Edition xxvii}

Bridge. I no longer remember whether they were from São Paulo or from Minas, but I know that they impressed me as being the caricatures of men, and there came to mind a phrase from a book on Brazil written by an American traveler: "the fearfully mongrel aspect of the population." That was the sort of thing to which miscegenation led. I ought to have had some one to tell me then what Roquette Pinto had told the Aryanizers of the Brazilian Eugenics Congress in 1929: that these individuals whom I looked upon as representative of Brazil were not simply mulattoes or cafusos but sickly ones. ${ }^{6}$

It was my studies in anthropology under the direction of Professor Boas that first revealed to me the Negro and the mulatto for what they are-with the effects of environment or cultural experience separated from racial characteristics. I learned to regard as fundamental the difference between race and culture, to discriminate between the effects of purely genetic relationships and those resulting from social influences, the cultural heritage and the milieu. It is upon this criterion of the basic differentiation between race and culture that the entire plan of this essay rests, as well as upon the distinction to be made between racial and family heredity.

However little inclined we may be to historical materialism, which is so often exaggerated in its generalizations-chiefly in works by sectarians and fanatics-we must admit the considerable influence, even though not always a preponderant one, exerted by the technique of economic production upon the structure of societies and upon the features of their moral physiognomies. It is an influence subject to the reaction of other influences, yet powerful as no other in its ability to make aristocracies or democracies out of societies and to determine tendencies toward polygamy or monogamy, toward stratification or mobility. Studies in eugenics and cacogenics are still in a state of flux, and much of what is supposed to be the result of hereditary characteristics or tares ought rather to be ascribed to the persistence for generations of economic and social conditions favorable or unfavorable to human development. It is Franz Boas who, admitting the possibility

- Roquette Pinto, an anthropologist who died in 1954, was one of Brazil's most distinguished scientists. "Aryanization" has a special meaning in Brazil, with allusion to the absorption of the "inferior" races by the "superior" one (i.e., the white race), and the gradual shedding of the characteristics of the hybrid type. This view is set forth by J. F. de Oliveira
Vianna, among others, in his book, Populaçōes meridionaes do Brasil (3rd edition, São Paulo, 1933); see in particular p. 154. There is, however, a wide difference of opinion on the subject. See Donald Pierson: Negroes in Brazil (University of Chicago Press, I942), Chapter viii, "Racial Ideology and Racial Attitudes." (Translator.) 


\section{xxviii The Masters and the Slaves}

that eugenics may be able to eliminate the undesirable elements of a society, reminds us that eugenic selection should concern itself with suppressing the conditions responsible for the creation of povertystricken proletarians, sickly and ill-nourished; and he further reminds us that so long as such conditions exist, the result can only be the creation of more proletarians of the same sort. ${ }^{7}$

In Brazil the relations between the white and colored races from

${ }^{7}$ Boas stresses the fact that in those classes where the economic conditions of life are unfavorable, individuals evolve slowly and are low in stature in comparison with the wealthy classes. Among the poorer classes a low stature would appear to be hereditary, but capable none the less of modification once the economic conditions are modified. Bodily proportions, Boas tells us, are in some cases determined by occupation and are seemingly handed down from father to son when the son follows the same occupation as the father.-Franz Boas: Antbropology and Modern Life (New York and London, r929). See also the researches of H. P. Bouditch: "The Growth of Children," Eighth Annual Report of the State Bureau of Healtb of Massacbusetts. In Russia, as a result of the famine of $1921-2$, a famine due not only to the bad organization of the first Soviet administrations but also to the blockade of the new Republic by the capitalist governments, there was found to be a considerable decrease in the stature of the population.-I. Ivanovsky: "Physical Modifications of the Population of Russia under Famine," American Journal of Pbysical Antbropology, No. 4, 1923. On the other hand the studies of the North American population made by Hrdlička show an increase of stature.-Ales Hrdlixka: The Old Americans (Baltimore, 1925). On the differences in stature and other physical and mental characteristics between one social group and another, see the classic work of A. Niceforo: Les Classes pauvres (Paris, 1905); and among more recent studies, that of Pitirim Sorokin: Social Mobility (New York, 1927). As to the correlation between intelligence and social class, see the notable work by Professor L. M. Terman of Stanford University: Genetic Studies of Genius, 1925-30. The interesting thing in connection with these differences -the exceptional case naturally being excluded-is to determine to what point they are hereditary or genetic and at what point they cease to be, becoming instead the reflection of a favorable or unfavorable succession of economic conditions-that is to say, a reflection of the social milieu and the diet of rich and poor. Or-looking at the problem from another point of view-we may ask: what are the possibilities of qualities acquired and cultivated for generations becoming transmissible by heredity? Dendy stresses the observation of Oliver Wendell Holmes to the effect that an intellectual and social aristocracy had been formed in New England through the repetition of the same influences for generation after generation.-Arthur Dendy: The Biological Foundation of Society (London, 1924). On this point see also J. A. Detlefsen: Our Present Knowledge of Heredity (Philadelphia, 1925); H. S. Jennings: Prometheus (New York, 1925); C. M. Child: Physiological Foundations of Bebavior (New York, 1924); A. J. Herrick: Neurological Foundations of Animal Bebavior (New York, I924); F. B. Davenport: Heredity in Relation to Eugenics (New York, 1911); A. Myerson: The Inberitance of Mental Disorders (Baltimore, I925). 


\section{Preface to the Second English-Language Edition xxix}

the first half of the sixteenth century were conditioned on the one hand by the system of economic production-monoculture and latifundia - and on the other hand by the scarcity of white women among the conquerors. Sugar-raising not only stifled the democratic industries represented by the trade in brazilwood and hides; it sterilized the land for the forces of diversified farming and herding for a broad expanse around the plantations. It called for an enormous number of slaves. Cattle-raising, meanwhile, with the possibilities it afforded for a democratic way of life, was relegated to the backlands. In the agrarian zone, along with a monoculture that absorbed other forms of production, there developed a semi-feudal society, with a minority of whites and light-skinned mulattoes dominating, patriarchally and polygamously, from their Big Houses of stone and mortar, not only the slaves that were bred so prolifically in the senzalas, but the sharecroppers as well, the tenants or retainers, those who dwelt in the huts of mud and straw, vassals of the Big House in the strictest meaning of the word. ${ }^{8}$

Conquerors, in the military and technical sense, of the indigenous populations, the absolute rulers of the Negroes imported from Africa for the hard labor of the bagaceir ${ }^{9}{ }^{9}$ the Europeans and their descendants meanwhile had to compromise with the Indians and the Africans in the matter of genetic and social relations. The scarcity of white women created zones of fraternization between conquerors and conquered, between masters and slaves. While these relations between white men and colored women did not cease to be those of "superiors" with "inferiors," and in the majority of cases those of disillusioned and sadistic gentlemen with passive slave girls, they were mitigated by the need that was felt by many colonists of founding a family under such circumstances and upon such a basis as this. A widely practiced miscegenation here tended to modify the enormous social distance that otherwise would have been preserved between Big House and tropical forest, between Big House and slave hut. What a latifundiary monoculture based upon slavery accomplished in the way of creating an aristocracy, by dividing Brazilian society into two extremes, of

8 On the relation between building materials and the formation of aristocratic societies, see George Plekhanov: Introduction à l'bistoire sociale de la Russie (translation) (Paris, 1926).

9 The bagaceira was the place where the bagasse, or refuse of the sugarcane after the juice had been pressed from it ("cane trash"), was stored.
The word in Brazil comes to mean the general life and atmosphere of the sugar plantation. A famous modern novel by José Américo de Almeida is entitled $A$ Bagaceira (Rio de Janeiro, 1928); this work is looked upon as the beginning of the school of social fiction of the 1930's and the present day. (Translator.) 
gentry and slaves, with a thin and insignificant remnant of free men sandwiched in between, was in good part offset by the social effects of miscegenation. The Indian woman and the "mina"" ${ }^{10}$ or Negro woman, in the beginning, and later the mulatto, the cabrocba, ${ }^{11}$ the quadroon, and the octoroon, becoming domestics, concubines, and even the lawful wives of their white masters, exerted a powerful influence for social democracy in Brazil. A considerable portion of the big landed estates was divided among the mestizo sons, legitimate or illegitimate, procreated by these white fathers, and this tended to break up the feudal allotments and latifundia that were small kingdoms in themselves.

Bound up with a latifundiary monoculture were deep-rooted evils that for generations impaired the robustness and efficiency of the Brazilian population, whose unstable health, uncertain capacity for work, apathy, and disturbances of growth are so frequently attributed to miscegenation. Among other things, there was the poor supply of fresh food, subjecting the major part of the population to a deficient diet, marked by the overuse of dried fish and manihot flour (and later of jerked beef), or to an incomplete and dangerous one of foodstuffs imported under the worst conditions of transport, such as those that preceded the steamboat and the employment in recent years of refrigerator compartments on ships. The importance of the factor of hyponutrition, stressed by Armitage, ${ }^{12}$ McCollum and Simmonds, ${ }^{13}$ and of late by Escudero, ${ }^{14}$ a chronic hunger that comes not so much from a diet reduced in quantity as from its defective quality, throws a new light on those problems vaguely referred to as due to racial

\footnotetext{
10 Name given to highly respected Negro women of Bahia who became "friends," concubines, and "housewives" (donas de casa) of their white masters. The name is derived from Forte de el Mina on the west coast of Africa, one of the places from which the Portuguese imported their slaves. The "minas" were light-skinned, with features that resembled those of a white person, and were looked upon as "excellent companions." They were probably the first Negro women to be legally married to Europeans. See Donald Pierson: Negroes in Brazil, pp. 145-6. (Translator.)

11 A dark-skinned mestizo type. (Translator.)
}

12 F. P. Armitage: Diet and Race (London and New York, 1922).

${ }^{13} \mathrm{E}$. V. McCollum and Nina Simmonds: The Newer Knowledge of Nutrition: the Use of Foods for the Preservation of Vitality and Health (New York, 1929).

14 Pedro Escudero: "Influencia de la alimentación sobre la raza," La Prensa (Buenos Aires), March 27, 1933. The articles of the Argentine professor are interesting, even though they add little that is original to the studies of North American and European physiologists: Armitage, McCollum, Simmonds, Lusk, Benedict, McCay, Nitti. 


\section{Preface to the Second English-Language Edition xxxi}

"decadence" or "inferiority" and, thank God, offers greater possibilities of a solution. Prominent among the effects of hyponutrition are: a decrease in stature, weight, and chest measurement; deformities of the bony structure; decalcification of the teeth; thyroid insufficiency, pituitary and gonadial, leading to premature old age, a generally impoverished fertility, apathy, and, not infrequently, infecundity. It is precisely these characteristics of sterility and an inferior physique that are commonly associated with the execrated blood-stream of the so called "inferior races." Nor should we forget other influences that developed along with the patriarchal and slave-holding system of colonization: syphilis, for example, which is responsible for so many of those "sickly mulattoes" of whom Roquette Pinto speaks and to whom Ruediger Bilden attributes a great importance in his study of the formation of Brazilian society.

The formative patriarchal phase of that society, in its virtues as well as in its shortcomings, is to be explained less in terms of "race" and "religion" than in those of economics, cultural experience, and family organization; for the family here was the colonizing unit. This was an economy and a social organization that at times ran counter not only to Catholic sexual morality but to the Semite tendencies of the Portuguese adventurer toward trade and barter as well.

Spengler stresses the point that a race does not migrate from one continent to another; for that it would be necessary to transport along with it the physical environment. In this connection he alludes to the results of the studies of Gould and Baxter and those of Boas, which show that individuals of varying origin brought together under the same conditions of physical environment tend to a certain uniform development with regard to stature and even, perhaps, bodily structure and shape of the head..$^{15}$ The modifications, possibly due to environment, to be found in the descendants of immigrants-as in the case of the Sicilian and German Jews studied by Boas in the United States ${ }^{16}$-would appear to be the result chiefly of what Wissler calls the influence of the biochemical content. ${ }^{17}$ Indeed, the study of such modifications in a new climate or milieu is acquiring an ever greater importance. The rapid alterations that occur would seem to be due to the iodine that the environment contains, which

${ }^{15}$ Oswald Spengler: The Decline of the West (translation). (New York, 1926, 1928), Vol. II, p. Irg.

${ }^{16}$ Franz Boas: "Changes in Bodily Forms of Descendants of Immi- grants," Senate Documents (Washington, IgIo-11).

17 Clark Wissler: Man and Culture (New York, 1923). 


\section{xxxii The Masters and the Slaves}

acts upon the secretions of the thyroid gland. And diet is likewise of considerable importance in the differentiation of the physical and mental characteristics of the descendants of immigrants.

Admitting the tendency of the physical environment, and especially of the biochemical content, to re-create in its own image those individuals who come to it from various places, we still must not forget the action exerted in a contrary direction by the technical resources of the colonizers: their effect in imposing upon the environment strange cultural forms and accessories such as would permit the preservation of an exotic race or culture.

The patriarchal system of colonization set up by the Portuguese in Brazil and represented by the Big House was one of plastic compromise between the two tendencies. At the same time that it gave expression to the imperialist imposition of an advanced race upon a backward one, an imposition of European forms (already modified by colonizing experience in Asia and Africa) upon a tropical milieu, it meant a coming to terms with the new conditions of life and environment. The plantation Big House that the colonizer began erecting in Brazil in the sixteenth century-thick walls of mud or of stone and lime, covered with straw or with tile, with a veranda in front and on the sides and with sloping roofs to give the maximum of protection against the strong sun and tropical rains-was by no means a reproduction of Portuguese houses, but a new expression, corresponding to the new physical environment and to a surprising, unlooked-for phase of Portuguese imperialism: its agrarian and sedentary activity in the tropics, its rural, slave-holding patriarchalism. From that moment the Portuguese, while still longing nostalgically for his native realm, a sentiment to which Capistrano de Abreu has given the name of "transoceanism"-from that moment he was a Luso-Brazilian, the founder of a new economic and social order, the creator of a new type of habitation. One has but to compare the plan of a Brazilian Big House of the sixteenth century with that of a Lusitanian manor house (solar) of the fifteenth century in order to be able to perceive the enormous difference between the Portuguese of Portugal and the Portuguese of Brazil. After something like a century of patriarchal life and agrarian activity in the tropics, the Brazilians are practically another race, expressing themselves in another type of dwelling. As Spengler observes-and for him the type of habitation has a historical-social value superior to that of racethe energy of the blood-stream that leaves identical traces down the centuries must necessarily be increased by the "mysterious cosmic force that binds together in a single rhythm those who dwell in close 


\section{Preface to the Second English-Language Edition xxxiii}

proximity to one another." ${ }^{18}$ This force in the formation of Brazilian life was exerted from above downward, emanating from the Big Houses that were the center of patriarchal and religious cohesion, the points of support for the organized society of the nation.

The Big House completed by the slave shed represents an entire economic, social, and political system: a system of production (a latifundiary monoculture); a system of labor (slavery); a system of transport (the ox-cart, the banguê, ${ }^{19}$ the hammock, the horse); a system of religion (a family Catholicism, with the chaplain subordinated to the paterfamilias, with a cult of the dead, etc.); a system of sexual and family life (polygamous patriarchalism); a system of bodily and household hygiene (the "tiger," ${ }^{20}$ the banana stalk, the river bath, the tub bath, the sitting-bath, the foot bath); and a system of politics (compadrismo). ${ }^{21}$ The Big House was thus at one and the same time a fortress, a bank, a cemetery, a hospital, a school, and a house of charity giving shelter to the aged, the widow, and the orphan. The Big House of the Noruega plantation in Pernambuco, with its many rooms, drawing-rooms, and corridors, its two convent kitchens, its dispensary, its chapel, and its annexes, impresses me as being the sincere and complete expression of the absorptive patriarchalism of colonial times. An expression of the gentle and subdued patriarchalism of the eighteenth century, without the air of a fortress that characterized the first Big Houses of the sixteenth century. "On the plantations it was like being on a field of battle," writes Theodoro Sampaio, with reference to the first century of colonization. "The rich were in the habit of protecting their dwellings and manor houses by a double and powerful row of stakes, in the manner of the natives, and these stockades were manned by domestics, retainers, and Indian slaves and served also as a refuge for the neighbors when they were unexpectedly attacked by savages." 22

The plantations at the end of the seventeenth century and those of the eighteenth century, on the other hand, more nearly resembled

${ }^{18}$ Oswald Spengler, op. cit. The significance of the dwelling-place had already been stressed by G. Schmoller, in the classic pages that he has written on the subject.

19. In northeastern Brazil the banguê was a variety of litter with leather top and curtains. (Translator.)

20 The "tigre" was a vessel for the depositing and carrying away of fecal matter. (Translator.)
21 "Compadrismo" was a system of oligarchic nepotism and patronage; the author refers to it later in this chapter. From compadre: literally, a godfather or sponsor, a friend, etc. (Translator.)

22 Theodoro Sampaio: "S. Paulo de Piratininga no fim do século XVI" ("S. Paulo de Piratininga at the End of the Sixteenth century), Revista do. Instituto Histórico de Säo Paulo, Vol. II. 
a Portuguese convent-a huge estate with the functions of a hospital and a house of charity. The indescribable air of aloofness that characterized the houses at the beginning of the seventeenth century, with their verandas that appeared to have been erected on wooden stilts, was no longer to be met with in these end-of-the-century dwellings and those of the eighteenth and the first half of the nineteenth century; the latter were houses that had been almost wholly demilitarized and, accentuatedly rustic in appearance, offered to strangers an easygoing and expansive hospitality. Even on the cattle ranches of Rio Grande, Nicolão Dreys, at the beginning of the nineteenth century, encountered a custom reminiscent of medieval convents, that of ringing a bell at the dinner hour: "It serves to advise the traveler wandering over the countryside or the destitute of the vicinity that they may come to the lord of the manor's table which is now being spread; and, indeed, whoever cares to do so may and does sit down at that hospitable board. Never does the lord of the manor repel anyone or so much as ask him who he is. . . ." ${ }^{23}$

It seems to me that José Marianno fils is not entirely right in saying that our patriarchal architecture did no more than follow the model of religious architecture as developed here by the Jesuits, ${ }^{24}$ those terrible enemies of the lords of the plantation. What the architecture of the Big Houses took from the monasteries was, rather, a certain Franciscan gentleness and simplicity, a fact that is to be explained by the identity of functions fulfilled by a plantation manor house and a typical convent of Franciscan friars. There is no doubt (and I here find myself in perfect agreement with José Marianno fils) that Jesuit and Church architecture was the highest and most cultured expression of its kind in colonial Brazil, and it certainly had its effect upon the Big House. The latter, however, following a rhythm of its own, its own patriarchal tendency, and conscious of a larger need than that of a purely ecclesiastical adaptation to environment, proceeded to individualize itself and came to take on so great an importance that it ended by dominating the architecture of convent and church, breaking with the lofty Jesuit style and leveling the Spanish verticality, to make of it a gentle, humble, and subservient expression in the form of the plantation chapel, a dependency of the domestic habitation. If the Big House took from the churches and monasteries

e3 Nicolao Dreys: Notícia Descriptiva da Província do Rio Grande de Säo Pedro do Sul (Descriptive Account of the.Province of Rio Grande de São Pedro do Sul) (Rio de Janeiro, 1839), p. 174 .

24 José Marianno fils: Lecture in the School of Fine Arts of Recife, April 1933. 


\section{Preface to the Second English-Language Edition $\mathrm{xxxv}$}

artistic values and technical resources, the churches likewise assimilated the characteristics of the manor house: the entryway, for example. Nothing is more interesting than certain churches in the interior of Brazil with a veranda in front or along the sides, like a private residence. I am acquainted with a number of them, in Pernambuco, in Paraíba, in São Paulo. Quite characteristic is the Church of São Roque de Serinhaem, and still more so the chapel of the Caieira plantation, in Sergipe, whose aspect at a distance is wholly residential. And in São Paulo there is the little Chapel of São Miguel, which also dates from colonial times.

The Big House in Brazil, in the impulse that it manifested from the very start to be the mistress of the land, overcame the church. It overcame the Jesuit as well, leaving the lord of the manor as almost the sole dominating figure in the colony, the true lord of Brazil, or nearer to being than either the viceroys or the bishops.

For power came to be concentrated in the hands of these country squires. They were the lords of the earth and of men. The lords of women, also. Their houses were the expression of an enormous feudal might. "Ugly and strong." Thick walls. Deep foundations, anointed with whale oil. There is a legend in the northeast to the effect that a certain plantation-owner, more anxious than usual to assure the perpetuity of his dwelling, was not content until he had had a couple of slaves killed and buried beneath the foundation stones. The sweat and at times the blood of Negroes was the oil, rather than that of the whale, that helped to give the Big House foundations their fortresslike consistency.

The ironical part of it is, however, that owing to a failure of the human potential all this arrogant solidity of form and material was very frequently wasted, and in the third or fourth generation enormous houses built to last for centuries would begin crumbling from disuse or lack of proper care, the great-grandsons or even the grandsons being unable to preserve the ancestral heritage. In Pernambuco the ruins of the big country house of the barons of Mercês are still to be seen, and it is evident that even the stables were built like fortresses. But all this pomp has long since turned to dust, and when all is said, it was the churches that survived the Big Houses. At Massangana, the plantation where Nabuco ${ }^{25}$ spent his boyhood, the old manor house has disappeared and the senzala also has crumbled; only the ancient and diminutive Chapel of São Mateus remains standing, with its saints and its catacombs.

\footnotetext{
${ }^{25}$ Joaquim Nabuco was a famous abolitionist leader and intellectual of the later nineteenth century. (Translator.)
} 
The custom of burying the dead underneath the house-beneath the chapel, which was an annex of the house-is quite characteristic of the patriarchal spirit of family cohesiveness. The dead thus remained under the same roof as the living, amid the saints and the floral offerings of the devout. The saints and the dead were, indeed, a part of the family. In Portuguese and Brazilian cradle songs mothers never hesitated to make of their infant sons the younger brothers of Jesus, with the same rights to Mary's care, to the guardianship of Joseph, and the doting ministrations of St. Anne. St. Joseph was the one who was called upon with the least ceremony to rock the cradle or hammock of the child:

Rock, Joseph, rock,

For the Lady, she is out:

She's gone to Belem creek,

To wash the baby's clout. ${ }^{26}$

As for St. Anne, she was supposed to take the little ones on her lap and cuddle them:

Mistress St. Anne, come tend

My little daughter bere;

Just see bow pretty she is

And what a little dear.

This little girl of mine

Does not sleep in a bed;

She sleeps in the blessed lap

Of the good St. Anne instead.27

So much liberty was taken with the saints that to them was entrusted the task of protecting the jars of preserves against the ants:

Praise St. Benedict, 'tis a sin

That ants should come bere

To enter in.28

Such the inscription that was posted on the pantry door. Another was put up on the windows and house doors:

Jesus, Mary, Joseph,

Pray for us, do, who bave recourse to you..$^{29}$

26 Embala, Jose, embala, que a Senbora logo vem: foi lavar sez cueirinbo no riacbo de Belem.

27 Senbora Sant' Ana, ninai minba filba; vede que lindeza e que maravilha.
Esta menina

não dorme na cama, dorme no regafo do Senbora Sant Ana.

$28 \mathrm{Em}$ louvor de $S$. Bento que nāo venbam as formigas cá dentro.

20 Jesús, Maria, José, rogai por nós que recorremos a vós. 


\section{Preface to the Second English-Language Edition xxxvii}

Whenever a thimble, a coin, or object of value was lost, it was St. Anthony who had to account for it. In Brazilian patriarchal society, even more than in Portugal, there never ceased to be this perfect intimacy with the saints. About the only thing the Infant Jesus did not do was to get down on all fours with the children of the household, smear himself with guava jelly, and play with the Negro lads. The Portuguese nuns in their ecstasies would often feel him seated on their laps and playing with their sewing or tasting the sweets that they were preparing. ${ }^{30}$

Beneath the saints and above the living in the patriarchal hierarchy were the dead, who in so far as possible ruled and kept watch over the lives of their children, grandchildren, and great-grandchildren. In many a Big House their portraits were preserved in the sanctuary among the images of the saints, with a right to the same votive lamp and the same flowers. Sometimes also women's braids and the curls of infants were kept. It was, in short, a cult of the dead that puts one in mind of that of the ancient Greeks and Romans.

But the patriarchal Big House was not only a fortress, chapel, school, workshop, house of charity, harem, convent of young women, and hospital; it fulfilled another important function in Brazilian economy: it was also a bank. Within its thick walls, in the ground beneath the bricks or tiles, money was buried and jewels, gold, and other valuable objects were stored. The jewels were sometimes kept in the chapel, being used to adorn the saints; whence all the images of Our Lady, laden down in the Bahian manner with trinkets of all sorts, with balangandans, ${ }^{31}$ hearts, little horses, little dogs, gold chains, and the like. Thieves in those days were Godfearing and rarely ventured to enter the chapel and rob the sacred images. True, a certain thief did steal the halo and other jewels of

30 The infant Jesus used to come to aid Sister Mariana de Beija in "winding her wool and thread" as she sewed, and the same thing happened to the Venerable Mother Rosa Maria de Sto. St. Anthony would put in an appearance to play with the spinningwheel, etc.-Gustavo de Matos Sequeira: Relação de Varios Casos Notaveis e Curiosos Sucedidos em Tempo na Cidade de Lisboa, etc. (Account of Various Notable and Curious Happenings in the City of Lisbon, etc.) (Coimbra, 1925).

31 Donald Pierson (Negroes in Bra- zil, p. 246) says: "The balangandan ... consisted of a gold or silver frame on which were hung gold or silver images of animals, birds, fowls, fish, flowers, parts of the human body, houses, household utensils, amulets (including gold or silver balls inclosing soil from a cemetery), bells, medallions with religious significance, angels, suns, moons, etc. It was worn on festive occasions, tied at the waist. ... A limited number may still be seen among the heirlooms of wealthy Bahians." (Translator.) 


\section{Xxxviii}

\section{The Masters and the Slaves}

São Benedito, but his excuse, one that carried weight in those days, was that "a Negro ought not to be adorned so luxuriously"; and indeed, in colonial times, the use of "ornaments of a certain price" came to be forbidden to blacks. ${ }^{32}$

For safety's sake and as a precaution against pirates, against demagogic excesses, and against the communistic tendencies of the natives and the Africans, the proprietors of the big landed estates in their excessive zeal for private property would bury beneath their houses jewels and gold just as they did their beloved dead. These two motives were always uncannily mingled in the folklore of the Big Houses: with empty rocking-chairs rocking away on loosened tiles and leaving no trace on the morrow; with dishes clattering in the cupboard at night; and with the souls of departed lords of the manor appearing to relatives and even to strangers, begging Our Father's and Hail Mary's as they moaned and groaned and pointed out the places where barrels of money were to be found. This at times was the money of others, of which the owners of the house had illegally possessed themselves, money that friends, widows, and sometimes slaves had entrusted to them for safekeeping. Many of these poor folk were shorn of all they had and ended in utter poverty, owing to the sharp dealing or sudden death of the one with whom they had deposited their treasure. There were certain unscrupulous gentry who, accepting valuable objects in this manner, later pretended to be strangers who knew nothing whatever about the transaction: "Are you crazy? You mean to say you gave me something to keep for you?" 33 Often money that had been buried disappeared mysteriously. Joaquim $\mathrm{Na}$ buco, who had been reared by his godmother in the Big House of Massangana, died without ever knowing what became of the store of gold which the good lady had scraped together for him and which was probably buried in some hole in the wall. When Nabuco was Brazilian Minister in London, an old priest told him of the treasure that Dono Ana Rosa had saved for him, but not a pound of it was ever discovered. In various instances, in Bahia, Olinda, and Pernambuco, in the course of the work of demolition or excavation, kegs of money have been found beneath the houses. This happened in the

32 Letters royal of September 3, 1709 , and proclamation of 1740 , in Maranhão, cited by Agostinho Marques Perdigāo Malheiro: $A$ Escravidão no Brasil, Ensaio jurídico-bistóricosocial (Slavery in Brazil, a Juridical-
Historical-Social Essay) (Rio de Janeiro, 1866 ).

33 J. da Silva Campos: "Tradiçōes baianas" ("Bahian Traditions"), Revista do Instituto Geográphico e Histórico da Baia, No. 56. 


\section{Preface to the Second English-Language Edition xxxix}

case of the Pires d'Avila, or Pires de Carvalho, manor in Bahia, where in a corner of the wall there was found "a veritable fortune in gold coins." In other cases all that has been dug up is the bones of slaves, executed by their masters and buried in the garden or inside the house without the authorities knowing anything about it. It is related that the Viscount of Suassuna on his estate at Pombal had caused to be buried in the garden more than one Negro, victim of his patriarchal justice. There is nothing surprising in this, for there were those who even had their own sons put to death. One of these patriarchs, Pedro Vieira, by that time a grandfather, upon discovering that his son was having relations with a favorite slave girl, had him slain by an older brother. "It was that God's will might be done that I had my son killed," he wrote to the father coadjutor of Canavieira after the terrible order had been carried out. ${ }^{34}$

The friars, also, fulfilled the function of bankers in colonial times. Much money was given to them to keep in their monasteries, ${ }^{35}$ which were as strong and inaccessible as fortresses. Whence the legends, so common in Brazil, of convent cellars with money still buried there. It was chiefly the Big Houses, however, that served as banks in the colonial economy; and it was almost always the suffering souls of plantation-owners that would appear beseeching Our Fathers and Hail Mary's.

The Big House ghosts are in the habit of making their presence known by apparitions and noises that are practically the same throughout Brazil. A short while before the manor of Megaipe was stupidly demolished by dynamite, I had occasion to collect from the residents of the vicinity ghost stories connected with the old seventeenth-century dwelling. These tales had to do with the clatter of dishes heard in the dining-room; the sound of merry laughter and dance steps from the drawing-room; the rattling of swords; the swish and rustle of feminine silk; lights that were suddenly kindled and extinguished all over the house; moans and the clank of dragging chains; the weeping of a child; and apparitions of the grow-andshrink variety. Similar ghosts, so I was informed in Rio de Janeiro and in São Paulo, inhabit the ruins of the Big Houses in the valley of

3t Tristão de Alencar Araripe: "Peter-familias no Brasil dos tempos coloniais" ("The Paterfamilias in Colonial Brazil"), Revista do Instituto Histórico e Geográpbico Brasileiro, Vol. LV.
35 José Vieira Fazenda: "Antigualhas e memorias do Rio de Janeira" ("Antiquities and Reminiscences of Rio de Janeiro"), Revista do Instituto Histórico e Geográpbico Brasileiro, tomo 95, Vol. CXLIX. 
the Paraiba. ${ }^{38}$ And in Recife I learned from one old inhabitant that every night at midnight there issues forth from the chapel of the Big House that formerly belonged to Bento José da Costa a very pretty young woman clad in white who customarily goes mounted on a donkey like Our Lady. This is possibly the daughter of old Bento, fleeing the patriarchal tyranny of a father who had forbidden her to marry Domingos José Martins. For these ghosts commonly embody all the joys, sorrows, and most characteristic actions of the life of the manor houses.

In contrast to the adventurous nomad life of the bandeirantes ${ }^{37}$ -the majority of whom were mestizos, part white and part Indianthe Big House gentry represented, in the formation of Brazilian society, the most typical of Portuguese tendencies: namely, settledness, in the sense of a patriarchal stability. A stability based upon sugar (the plantation) and the Negro (the slave hut). Not that I am here suggesting an ethnic interpretation in place of the economic. I would merely set alongside the purely material or Marxist aspect of things or, better, tendencies the psychologic aspect. Or the psycho-physiologic. The studies of Cannon ${ }^{38}$ on the one hand, and on the other those of Keith, ${ }^{38}$ would seem to indicate that, independently of the economic pressure, societies like individuals are acted upon by psycho-physiologic forces presumably susceptible to control for the benefit of future scientifically formed élites-the forces of pain, fear,

36 Also in Minas. On the abandoned
estate of Samangolê, in the municipal-
ity of Paracatu, there was until re-
cently a ghostly ball that was held on
St. John's Night, attended by peo-
ple from all over the countryside, who
came in carriages and litters, escorted
by pages, etc. The orchestras played
the whole night long; but at dawn
there would be no trace of it all. Of
late these apparitions have ceased.
s7 The bandeirantes were members
of the bandeiras or armed bands of
the São Paulo region that in the eight-
eenth century, like our own "forty-
niners" the century. following, went
in search of the gold, silver, diamonds,
emeralds, and other hidden wealth
of the interior, which had become the
subject of legend and fable. (They
also sought the Indian to sell as a
slave.) The bandeirantes were bold,
adventurous spirits and by their en- ergy and intrepidity did much to open up the pathways to the backlands, thereby contributing to the expanding national consciousness and pride. For a colorful work on this subject, the reader of Portuguese may be referred to the volume by the artist Belmonte: No Tempo dos Bandeirantes (São Paulo, 1939). For comparatively recent and learned studies, see Vida e Morte do Bandeirante, by Professor Alcantara Machado (São Paulo, 1930); and História Geral das Bandeiras Paulistas, by Professor Affonso d'E. Taunay. (Translator.)

${ }^{38}$ Walter B. Cannon: Bodily Changes in Pain, Hunger, Fear and Rage (New York and London, 1929).

${ }^{39}$ Arthur Keith: "On Certain Factors Concerned in the Evolution of Human Races," Journal of the Royal Antbropological Institute, London, Vol. XLVI. 


\section{Preface to the Second English-Language Edition xli}

anger, alongside the emotions of hunger, thirst, and sex-forces that are possessed of a great intensity of repercussion. Thus Islamism, in its imperialist fury and in its formidable achievements, in its mystic exaltation of the sensual pleasures, would be the expression not simply of economic motives, but of psychological forces that have developed in a special manner among the populations of North Africa. And the same may be said of the activity of the bandeiras, with the generalized emotions of fear and anger asserted through reactions marked by a high degree of combativeness. The purer type of Portuguese, who came to settle as lord of the plantation, being dependent upon the Negro rather than upon the Indian, represents, it may be, in his tendency toward stability a psychologic specialization in contrast to the tendency manifested by the Indian and the mestizo (mixture of Indian with Portuguese) toward mobility. This is not to overlook the fact that in Pernambuco and in the Reconcavo the soil is exceptionally favorable to the intensive cultivation of sugar as well as to an agrarian, patriarchal, and stable existence.

The truth of the matter is that around the plantation-owners was created the most stable type of civilization to be found in Hispanic America, a type that is illustrated by the squat, horizontal architecture of the Big Houses: enormous kitchens; vast dining-rooms; numerous rooms for the sons and guests; a chapel; annexes for the accommodation of married sons; small chambers in the center for the all but monastic seclusion of unmarried daughters; a gynæceum; an entryway; a slave hut. The style of these Big Houses-style in the Spenglerian sense-might be a borrowed one, but its architecture was honest and authentic. Brazilian as a jungle plant. It had a soul. It was a sincere expression of the needs, interests, and the broad rhythm of a patriarchal life rendered possible by the income from sugar and the efficient labor of Negro slaves.

This honesty, this expansiveness without luxurious display, was sensed by various foreign travelers, from Dampier to Maria Graham, who visited colonial Brazil. Maria Graham was enchanted with the residences in the vicinity of Recife and with the plantation houses in the province of Rio de Janeiro. The only bad impression that she got was due to the excessive number of bird and parrot cages hung up everywhere. But these parrot cages merely served to confer upon family life a bit of what today would be called local color. As for the parrots themselves, they were so well trained, Mrs. Graham adds, that they rarely screamed at the same time. ${ }^{40}$ So far as that goes, d'As-

40 Maria Graham: Journal of a Voyage to Brazil and Residence There during the Years 1821, 1822, 1823 (London, 1824), p. 127. 
sier notes a still more significant instance: that of monkeys receiving the benediction from Negro lads, just as the lads received it from the aged blacks, who in turn were blessed by their white masters. ${ }^{41}$ The hierarchy of the Big Houses was extended even to parrots and monkeys.

The Big House, although associated particularly with the sugar plantation and the patriarchal life of the northeast, is not to be looked upon as exclusively the result of sugar-raising, but rather as the effect of a slave-holding and latifundiary monoculture in general. In the south it was created by coffee, in the north by sugar; and it is as Brazilian in the one case as in the other. In traveling through the old coffee-plantation zone of the Rio Grande and São Paulo region, one sees the ruins of former mansions with the land round about bleeding still from the wounds of the ax and the processes of latifundiary labor, and one realizes that they are the expression of the same economic impulse that in Pernambuco created the Big Houses of Megaipe, of Anjos, of Noruega, of Monjope, of Gaipió, of Morenos, laying waste a considerable part of the region known as "mata," or jungle forest. It is true that certain variations are to be noted, some of them due to a difference in climate, others to psychological contrasts, and to the fact that, in São Paulo at least, a latifundiary monoculture was a regime imposed at the end of the eighteenth century upon a system of small ownership. ${ }^{42}$ In passing we should not overlook the fact that "while the inhabitants of the north sought out for their habitations

41 Adolphe d'Assier: Le Brésil contemporain-Races - Mceurs - Institutions-Paysages (Paris, 1867 ), p. 89.

42 Alfredo Ellis, Jr., in Raça de Gigantes (Race of Giants), basing his statements upon the old Inventories and Allotments of colonial days, asserts that down to the end of the eighteenth century a small-property regime was the dominant one in São Paulo, the dwelling-houses being no more than stucco-walled structures, originally covered with sapé. "They ordinarily had three rooms with a garden and were very badly furnished. ..." They were, however, very large, with enormous diningrooms, and already had a "house for Negroes," or senzala. In the seventeenth-century house of Francisco Mariano da Cunha the same writer found sixteen rooms of huge dimensions and a dining-room 13 meters by 5.4 [about 43 feet by 18 ]. Oliveira Vianna, in his Populações Meridionais do Brasil (Soutbern Populations of Brazil), stresses the contrast between the São Paulo plantations prior to the century (the nineteenth) in which coffee was introduced-"diminutive estates measured in cubits, the majority of them being a league in circumference"-and "the estates of Minas and the Rio Grande region, which are latifundia of 10,000 alquiers or more." But the real latifundia were those of Pernambuco and Bahia, of the type of the Garcia d'Avila plantation.

[The alquier (alqueire) is a land measure varying in extent from $\mathbf{2 4 . 2}$ to 48.4 square meters. (Translator.)] 


\section{Preface to the Second English-Language Edition xliii}

elevated sites, on the mountain slopes, the Paulistas commonly preferred the lowlands, the depressions of the earth, as the place to erect their dwellings. . . ." ${ }^{43}$ These latter houses were "always built on a steeply inclined slope as a protection against the south wind, in such a manner that on the lower side the house had a ground floor that gave it the appearance of a two-story edifice." The southern mansions have more of a closed-in, aloof air than do the houses of the north; but the "terrace from which the planter with his gaze could take in the entire organism of rural life" is the same as in the north, a terrace that is pleasing, hospitable, and patriarchal in character. Coming down the river from Santos to Rio in a small steamer that puts in at all the ports along the way, one has a glimpse at the water's edge-in Ubatuba, São Sebastião, Angra dos Reis-of town houses that recall the patriarchal dwellings of Rio Formoso. And at times, as in the north, one encounters churches with a porch in frontgently inviting and typically Brazilian.

The social history of the Big House is the intimate history of practically every Brazilian: the history of his domestic and conjugal life under a slave-holding and polygamous patriarchal regime; the history of his life as a child; the history of his Christianity, reduced to the form of a family religion and influenced by the superstitions of the slave hut. The study of the intimate history of a people has in it something of Proustian introspection-the Goncourts had a name for it: "ce roman vrai." The architect Lúcio Costa has given us his impression in the presence of the old mansions of Sabará, São João d'ElRe, Ouro Preto, and Mariana, the old Big Houses of Minas: "How one meets oneself here. . . . And one remembers things one never knew but which were there inside one all the while; I do not know how to put it -it would take a Proust to explain it." 44

It is in the Big Houses that, down to this day, the Brazilian character has found its best expression, the expression of our social continuity. In the study of their intimate history, all that political and military history has to offer in the way of striking events holds little meaning in comparison with a mode of life that is almost routine; but it is in that routine that the character of a people is most readily to be discerned. In studying the domestic life of our ancestors we feel that we are completing ourselves: it is another method of search-

43 João Vampré: "Fatos e festas na tracição" ("Facts and Festivals as Handed Down by Tradition"), in the Revista do Instituto Histórico de São Paulo, Vol. XIII.
44 Lúcio Costa: "O Aleijadinbo e a Arquitetura Tradicional" ("Aleijadinho and Traditional Architecture"), O Jornal, Rio de Janeiro, special Minas Geraes edition. 


\section{xliv The Masters and the Slaves}

ing for the "temps perdu," another means of finding ourselves in others, in those who lived before us and whose life anticipates our. own. The past awakens many strings and has a bearing on the life of each and every one of us; and the study of this past is more than mere research and a rummaging in the archives: it is an adventure in sensitivity.

This becomes clear when we succeed in penetrating the past's intimate secrets, in discovering its true tendencies in its homely, unaffected aspects and most sincere forms of expression. All of which is not an easy thing in a country like Brazil, where the confessional absorbs personal and family secrets and provides an outlet for that passion for self-revelation on the part of men, and especially of women, which the student of history meets with in Protestant countries in all the intimate diaries, confessions, letters, memoirs, autobiographies, and autobiographical novels that are at his disposal. I do not believe that in Brazil there has ever been a single diary written by a woman. Our grandmothers, so many of them illiterate even when they happened to be baronesses and viscountesses, were content to tell their secrets to their father confessor or to their favorite slave girl, and their propensities to gossip were almost wholly satisfied by conversations with their black-skinned maids on rainy afternoons or in the depressing heat of scorching noontides. In vain would one look for the gossip-filled diary of a mistress of the house of the sort to be encountered among the British and North Americans of colonial times. ${ }^{45}$

45 There do exist "livros de assentos," or memoranda books kept by plantation-owners. Thanks to the kindness of an aged relative of mine, Dona Maria (Iaiá) Cavalcanti de Albuquerque Mello, I was permitted to inspect the "book of special memoranda" that was begun in Olinda on March I, 1843 by her father, Felix Cavalcanti de Albuquerque Mello (1821-1901), containing not only matters of interest to the family of Francisco Casado de Hollanda Cavalcanti de Albuquerque (1776-1832), former owner of the Jundiá plantation, which was sold in 1832 , and to the families of his sons and sons-inlaw, but items of general interest as well-a cholera epidemic, a riot against the Portuguese, the hecatomb of Vitória, etc.

[Selections from the "livro de assento" in question have since been edited by Freyre under the title Memórias de um Cavalcanti (São Paulo, 1940). The anti-Portuguese riot, or "mata-mata-marinbeiro," referred to occurred on June $26-7,1847$, when Brazilians rose up against the Portuguese merchants and traders of the city of Recife, with much consequent bloodshed. The Brazilians or "liberals" objected to the fact that retail trade was being monopolized by the Portuguese. The term matamata-marinbeiro comes from the cry used by the Brazilians in the course of the rioting, marinbeiro (literally, a 


\section{Preface to the Second English-Language Edition xlv}

On the other hand, the Inquisition kept its enormous and watchful eye trained upon the intimate life of the colonial era, upon the bedrooms and the beds (usually, it would appear, made of leather) that creaked beneath the weight of adulteries and forbidden intercourse; upon the small chambers and the rooms occupied by the saints; upon the relations of the white masters with their slaves. The confessions and denunciations resulting from the visitation of the Holy Office to Brazil ${ }^{46}$ afford precious material for the study of Brazilian sexual and family life in the sixteenth and seventeenth centuries. They show us, among other things: the age at which young girls married-from twelve to fourteen; the principal pastime of the colonists-the game of backgammon; and the dramatic pomp of the religious processions - with men clad as Christ and other figures of the Passion and with the devout carrying sweetmeat boxes from which to feed the penitents. They enable us to behold the heresies of the new-Christians and the "Holiness" sects, their mingling of Christianity and witchcraft, their roguish festivals inside the churches, with merrymakers seated on the altars singing trovas ${ }^{47}$ and playing the guitar; and along with all this, irregularities in the domestic and moral life of the Christian family: married men marrying a second time with mulatto women; others sinning against nature with effeminates of the country or from Guinea; still others committing with women the lewd act that in modern scientific language as well as in the classics is known as felatio, and which the denunciations describe in minute detail; foul-mouthed individuals swearing by the "Virgin's muff"; ${ }^{48}$ mothers-in-law planning to poison their sons-in-law; new-Christians plac-

sailor) being roughly equivalent to gringo-"kill-kill-the-gringo."-"The hecatomb of Vitória" is an allusion to the heavy toll of life taken by the cholera epidemic in that city. (Translator.)]

${ }^{46}$ Primeira Visitação do Santo Oficio as Partes do Brasil, pelo licenciado Heitor Furtado de Mendonça-Confissões da Baía-1591-92 (First Visitation of the Holy Office to the Regions of Brazil, by the Licentiate Heitor Furtado de Mendonça-Confessions of Babia, etc.) (São Paulo, 1922). Primeira Visitàção do Santo Ofício as Partes do Brasil, etc. -Denunciações da Baia-1591-1593 (First Visitation, etc.-Denunciations of
Babia) (São Paulo, 1925). Primeira Visitação do Santo Of́́cio as Partes do Brasil, etc.-Denuncią̧óes de Pernambuco (First Visitation, etc.Denunciations of Pernambuco) (São Paulo, 1929). These documents form a part of the Eduardo Prado series, published by Paulo Prado; the first two volumes bear introductions by Capistrano de Abreu; the third has an introduction by Rodolfo Garcia.

${ }^{47}$ The trova is a poetic form that stems from the love songs of the medieval troubadours of the Iberiap Peninsula. (Translator.)

48 "Pelo "pentelbo da Virgem." The pubic hair. (Translator.) 
ing crucifixes beneath the bodies of women at the moment of copulation or tossing them into urinals; lords of the manor having pregnant slave girls burned alive in the plantation ovens, the unborn offspring crackling in the heat of the flames.

There were also-this was in the eighteenth and nineteenth centuries-certain dandies, shabby versions of Mr. Pepys, who had the habit of methodically collecting in notebooks bits of spicy gossip and who were known as "gatherers of facts." Manuel Querino mentions them in connection with Bahia; Arrojado Lisboa, in a conversation that I had with him, told me of some of them having to do with Minas; ${ }^{49}$ and in Pernambuco, in the old rural region, I have met with traces of them. Some of these "gatherers of facts" anticipated the authors of the pasquinades by collecting shameful incidents that, at the opportune moment, might serve to cast a blot upon respectable names or escutcheons. As a rule they exploited cases where the possession of white and noble blood was assumed, by digging up some remote female ancestor who had been a slave or a "mina," some uncle who had served a prison sentence, some grandfather who had fled the Inquisition. The moral and sexual irregularities of ancestors were all duly chronicled, including those of the ladies.

There are other documents that are of assistance to the student of the intimate history of the Brazilian family: inventories, such as those that the former President of Brazil, Washington Luis, caused to be published in São Paulo; letters of allotment; wills; court cor-

${ }^{49}$ I had the good fortune to come upon these notebooks in the course of a recent journey to Minas. Some were found in Caeté, others in Belo Horizonte, in the hands of a private individual who kindly permitted me to read them. They represent the patient and, everything would indicate, the scrupulous labors, not of a mere talebearer, but of an old municipal archivist who died years ago: Luis Pinto. Pinto spent his life rummaging among the archives, the legal documents, marriage and birth records, wills, etc., in the genealogical collections of some of the most important Minas families. By means of these data I had the pleasure of verifying some of the generalizations that $I$ had ventured to set forth in the first edition of this work regarding the for- mation of the family in those regions of Brazil where there was the greatest scarcity of white women. Thus, Jacintha de Siqueira, "the celebrated African woman who at the end of the seventeenth or beginning of the eighteenth century came with various bandeirantes from Bahia," and "to whom is due the credit for the discovery of gold in the Quatro Vintens ravine and the founding of the settlement at Villa Nova do Principe in I 714," is seen to be identified with the matriarchal trunk, so to speak, of a whole group of illustrious families in our country. "The fathers of all the sons of Jacintha de Siqueira," adds the genealogist, "were rich and important individuals, and many of them were prominent in the government. . . ."Among others there was a majorgeneral. 


\section{Preface to the Second English-Language Edition xlvii}

respondence and royal decrees such as those that exist in manuscript form in the Library of the State of Pernambuco or are scattered about in old registry offices and family archives; the pastoral letters and reports of the bishops, such as that most interesting one by Friar Luis de Santa Thereza which, written in Latin and copied out in a fine ecclesiastical hand, lies yellowing in the archives of the Cathedral of Olinda; the proceedings of the tertiary orders, confraternities, and religious houses as preserved in the archives of the Tertiary Order of St. Francis in Recife, where they are inaccessible and useless (they have reference to the eighteenth century); the Interesting Documents for the History and Customs of São Paulo, ${ }^{50}$ of which Affonso de E. Taunay made so much use in his notable studies of colonial life in São Paulo; the Acts and the General Registry of the Cbamber of São Paulo; ${ }^{51}$ the registry-books of baptisms, deaths, and marriages of freedmen and slaves and those containing the roll of families and the proceedings in matrimonial cases such as are preserved in ecclesiastical archives; the genealogical studies of Pedro de Taques in São Paulo and of Borges da Fonseca in Pernambuco; the reports of hygiene committees; parliamentary documents; medical studies and theses, including doctoral theses submitted to the faculties of Rio de Janeiro and Bahia; the documents published by the National Archives, ${ }^{52}$ by the National Library, by the Brazilian Historical Institute in its Review, and those published by the Institutes of São Paulo, Pernambuco, and Bahia. I myself not only had the good fortune to come upon various letters from the Paranhos family which had been kindly placed at my disposal by my friend Pedro Paranhos; I also had access to another important family collection, unfortunately greatly damaged by moths and humidity but containing documents dating from colonial times: that of the Noruega plantation, which for long years was the property of Commander Manoel Thomé de Jesus and which was handed down to his descendants. It is highly desirable that what is left of these old collections belonging to private individuals be

50 Documentos interessantes para a bistória e costumes de São Paulo.

51 Atas and Registro Geral da Camara de Säo Paulo.

52 Among others, documents having to do with the land. In his preface to "Synopsis das Sismarias Registradas nos Livros Existentes no Arcbivo da Thesouraria da Fazenda da Babia" ("Synopsis of the Acts of Allotment Registered in the Books Existent in the Exchequer of the Plantation of Bahia"), Publicações do Arquivo Nacional, XXVII, Alcides Bezerra stresses the interest these documents hold for the sociologist, the anthroposociologist, and the simple genealogist. They constitute, indeed, a "foundation stone for Brazilian territorial history," and any interpretation of our social development must be based upon an acquaintance with them. 
brought together in libraries or museums, and that the ecclesiastical archives and those of the tertiary orders be conveniently catalogued. Various documents that are still in manuscript form in the archives and libraries ought to be published as soon as possible. I may perhaps be permitted to remark that it is regrettable that some of our historical reviews should devote page after page to the publication of patriotic addresses and literary gossip while so much material of strictly historjcal interest remains unknown or is difficult of access to students.

For a knowledge of the social history of Brazil no source is more dependable than the travel books written by foreigners-although it is necessary to exercise great discrimination betweeen superficial writers or those whose work, though suggestive or informative, is vitiated by preconceptions (the Thévets, Expillys, Dabadies) and the good and honest ones like Léry, Hans Staden, Koster, Saint-Hilaire, Rendu, Spix, Martius, Burton, Tollenare, Gardner, Mawe, Maria Graham, Kidder, and Fletcher. ${ }^{53}$ I have drawn largely upon these writers,

${ }^{53}$ Most of the authors mentioned are famous in their field. Jean de Léry, French Huguenot and a shoemaker by trade, has been called "the Montaigne of travelers." He was the author of a Histoire d'un voyage faict en la terre du Brésil (new edition, with Introduction and Notes by Paul Gaffarel, Paris, r $77^{\circ}$ ). A Portuguese translation of this work, Viagem á terra do Brasil (Voyage to the Land of Brazil), by the distinguished contemporary writer and scholar Sergio Milliet, was published at São Paulo in 1941. Hans Staden was the author of the first book published on Brazil, a famous work commonly known as the True History (Wabrbaftige Historia), first published at Marburg in 1557, and since translated into many languages. There is an English version: Hans Staden: The True History of His Captivity, 1557, Translated and Edited by Malcolm Letts (London, 1928; New York, 1929). For a Portuguese rendering, see Hans Staden: Meu Captiveiro entre os Selvagens do Brasil, edited by Monteiro Lobato (Rio de Janeiro, 1925). Henry Koster was the author of Travels in Brazil (London, 1816). Auguste de Saint-Hilaire wrote Voyages dans l'intérieur du Brésil (1852). A. Rendu's Études sur le Brésil was published at Paris in 1848. J. B. von Spix and C. F. P. von Martius were the authors of Reise in Brasilien (Munich, $1823-3 \mathrm{r}$ ); an English translation, Travels in Brazil, 1817-1820, was published at London in 1924. Richard F. Burton's Explorations of the Highlands of the Brazil appeared at London in 1869 . L. F. Tollenare was a French traveler who left manuscript notes on his residence in Brazil that have been published in Portuguese under the title: "Notas Dominicais Tomadas durante uma Residência no Brasil, 1816-1818" ("Dominical Notes Made during a Residence in Brazil," etc.); these notes appeared in part in the Revista do Instituto Arqueológico e Geográpbico Pernambucano, No. 6r (1905), the portion referring to Pernambuco being translated by Alfredo de Carvalho. George Gardner: Travels in the Interior of Brazil, Principally through the Northern Provinces (London, 1846). John Mawe: Travels in the Interior of Brazil (Philadelphia, I8,6). Maria Graham's work has been referred to; see note 40 above. The North Americans, Daniel P. Kidder and J. C. Fletcher, are the authors of 


\section{Preface to the Second English-Language Edition xlix}

putting to use here a familiarity, dating from my student days, with this species of -I shall not say literature, for most of these books ${ }^{54}$ are very badly written, even though they display at times a delightful and almost childlike candor. I had occasion to explore this field in connection with the research work for my master's thesis, Social Life in Brazil in the Middle of the 19th Century, submitted in 1923 to the Faculty of Political and Social Sciences of Columbia University. This study Henry L. Mencken did me the honor to read, and it was he who advised me to expand it into a book. The book in question, which is the present one, is accordingly indebted for this word of encouragement to the most antiacademic of critics.

To come back to the question of sources, mention must be made of the valuable data to be encountered in the letters of the Jesuits. Already a large amount of this material has been published; but a note from João Lúcio de Azevedo, an authority on the subject, reminds me that there must still be in the archives of the order a great deal that has not been printed. The Jesuits were not only great letterwriters, many of their letters touching on the intimate details of the social life of the colonists; they also sought to develop in their pupils, the caboclos and mamelucos, ${ }^{55}$ a taste for the epistolary art. Writing from Bahia in $155^{2}$, the Jesuit Francisco Pires, in speaking of the pilgrimages made by his young wards to the backlands, has this to say: ". . . I shall not undertake a description, for the reason that the Father has directed them to write to the young of Lisbon, and it may be that you will have seen their letters. . . ." It would be interesting to come upon these communications and see what the Brazilian

a well-known work: Brazil and the Brazilians (Boston, 1879). See also D. P. Kidder's Sketches of Residence and Travel in Brazil (Philadelphia, 1845 ). On Thevet, see Chapter ii, note 115 , p. ro3. (Translator.)

54 I have also at times, in transcribing passages from well-known travel accounts, made use of existing Portuguese translations, but have been careful always to check them with the original, correcting them in certain instances where I disagree with the translators. The texts of the oldest travel books-those-of the fifteenth, sixteenth, seventeenth, and eighteenth centuries and the early part of the nineteenth century-have been transcribed, where they are kept in the original, with all their archaisms. The same is true of the texts of the ancient Portuguese and Brazilian chronicles, treatises, and documents. Those works, looked upon as principal sources, have been indicated in this book where quotations from them appear.

${ }^{55} \mathrm{~A}$ mameluco is the offspring of white and Indian. It is sometimes employed as a generic term, embracing all varieties of mestizo, including the offspring of Negro and white, of Negro and Indian, etc. (Translator.) 
caboclos of the sixteenth century had to say to Lisbon. The letters of the Jesuits frequently contain valuable bits of information concerning social life in the first century of colonization and the contact of European culture with that of the native and the African. Thus, Father Antônio Pires, in a letter written in 1 552, describes for us a procession of Guinea Negroes in Pernambuco who had already been organized into a confraternity. They were all very orderly as they marched "one after another with their hands constantly upraised, as they all repeated: Ora pro nobis." The same Father Antônio Pires, in a letter from Pernambuco dated August 2, 155 I, alludes to the settlers on the land of Duarte Coelho as "the best folk to be found in all the capitânias." ${ }^{56}$ Another letter informs us that the Indians at first "were embarrassed in pronouncing Santa Joogaba, which in our language means: 'by the Sign of the Holy Cross'; for this impressed them as being a kind of foolish dumb show." ${ }^{57}$ As for Anchieta, ${ }^{58}$ he mentions the many poisonous insects that made life miserable for these first settlers, with jararacas ${ }^{59}$ crawling through the houses and dropping from the roofs upon the beds. "And when people awake they find them coiled around their necks or their legs, and when they go to put on their shoes in the morning they discover them there." Both Anchieta and Nobrega ${ }^{80}$ lay stress upon the sexual irregularities of the colonists, their relations with the Indians and the Negroes; and they mention the fact that the foodstuffs derived from the land were of poor quality, costing all of "three times what they do in Portugal." In connection with the natives, Anchieta had occasion to repeat the lament of Camões with respect to the Portuguese, speaking of their "lack of wit"-that is to say, of intelligence-a condition rendered worse by the fact that they would not apply themselves to study but were always ready for festivals, singing, and merrymaking. He also emphasizes the abundance of sweets and dainty

56 "The country was divided, rather empirically, into several provinces called capitânias, which were donated as fiefs to bankrupt Portuguese fidalgos who were to rule them as their captains." Erico Verissimo: Brazilian Literature: An Outline (New York: The Macmillan Company; 1945), p. 6. (Translator.)

57 Cartas Jesuíticas (1550-1568) (Jesuit Letters) (Rio de Janeiro, 1887), p. 4I.

${ }^{58}$ The Jesuit missionary José de An- chieta $(1530-97)$ is one of the first outstanding names in the literature of Brazil. (Translator.)

${ }^{69}$ The jararaca is a poisonous snake of Brazil (the Botbrops jararaca), brownish in color with red and black spots. (Translator.)

${ }^{60}$ Manoel de Nobrega is another important name in the early literature; his Cartas do Brasil (Letters from Brazil), I549-60, were published at Rio de Janeiro in 1886 . (Translator.) 


\section{Preface to the Second English-Language Edition}

repasts, orangeade, preserved squash, preserved marmelo, etc., all made with sugar. ${ }^{01}$ These are realistic and honest details such as are to be gathered in large number from the letters written by the padres, amid other data that is of purely religious or devotional interest. They are details that have a light to throw on those aspects of colonial life that are generally neglected by other chroniclers. Nor have we any cause to complain of laymen, who, in chronicles like those of Pero Magalhães de Gandavo and Gabriel Soares de Souza, also have afforded us significant and lively glimpses of the intimate life of the early colonists. Gabriel Soares even goes into details regarding the revenues of the plantation-owners, the material of which their houses and chapels were built, the food they ate, the confections and sweetmeats of the Big House kitchen, and the clothing that the ladies wore. A bit more of this sort of thing and he would have been a gossip like Pepys.

There are other sources that will afford information or, simply, offer suggestions to the student of the intimate life and sexual morality of Brazilians in the days of slavery: the rural folklore in those regions where slave labor has left its deepest imprint; manuscript notebooks containing popular songs and cake recipes; ${ }^{62}$ newspaper files; books of etiquette; and, finally, the Brazilian novel, which in the pages of some of our best writers affords many interesting details having to do with the life and customs of the old patriarchal family. One may mention: Machado de Assis in Helena, the Postbumous Memoirs of Braz Cubas, ${ }^{63}$ laiá Garcia, Dom Casmurro, and other of his novels and volumes of short stories; Joaquim Manuel de Macedo in Cruel Victims, ${ }^{64}$ The Brunette, ${ }^{65}$ The Blond Lad, ${ }^{66}$ and Women of the Mantilla, ${ }^{67}$ all of these being romances that are filled with

61 Joseph de Anchieta: Informações e Fragmentos Históricos (Historical Data and Fragments) (Rio de Janeiro, r 886 ), p. 37 .

62 I possess one of these notebooks that belonged to Gerôncio Dias de Arruda Falcão, for some time master of the Noruega plantation and a great gourmet. Seated in his rocking-chair, old Gerôncio would sometimes supervise the preparation of the finest of ragouts or desserts. I also have a song book that was formerly the property of my great-uncle Cicero Brasileiro de Mello.
${ }^{63}$ Menórias Póstumas de Braz Cubas.
64 Vitimas Algozes.
${ }^{65} A$ Moreninha.

${ }^{66} \mathrm{O}$ Moço Louro. A Moreninha and $O$ Moço Louro have delighted generations of Brazilians and have gone through numerous reprints. A new edition of $A$ Moreninba was published at Rio de Janeiro in 1943 . It is the custom of hyper-rsthetes to drop a sneer at Manuel de Macedo, but he was in many ways a true writer of the people. (Translator.) ${ }^{67}$ As Mulberes de Mantilba. 
"sinbazinbas," "iaiás," and "mucamas"; ${ }^{88}$ José de Alencar in Motber,"99 Luciola, Senhora, Familiar Demon, ${ }^{70}$ Ipê Trunk, ${ }^{71}$ Golden Dreams, ${ }^{72}$ and Gazelle's Hoof; ${ }^{73}$ Francisco Pinheiro Guimarães in the Story of a Rich Girl ${ }^{74}$ and Punishment; ${ }^{75}$ Manuel de Almeida in the Memoirs of a Militia Sergeant; ${ }^{76}$ Raul Pompéia in The Atbencum; ${ }^{77}$ and Júlio Ribeiro in Flesh. ${ }^{78}$ In addition there are Franklin Tavora, Agrário de Menezes, Martins Penna, Américo Werneck, and França Júnior, novelists, folklorists, or writers for the theater who with a greater or less degree of realism have set down characteristic aspects of the Brazilian's domestic and sexual life, ${ }^{79}$ having to do with the relations between master and slave, the work on the plantations, the festivals and processions, etc. The same thing was done in his own way-that is to say, through caricature-by the seventeenth-century satiric poet Gregório de Matos. In the field of memoirs and reminiscences the Viscount Taunay, Vieira Fazenda, and the two Mello Moraes have provided us with valuable data. ${ }^{80}$ There are in existence novels by foreigners undertaking to portray Brazilian life in the days of slav-

68 Terms expressive of the familiar and affectionate relations between master (or mistress) and slave. Compare our Southern "honey," "mammy," etc. Sinbazinba-diminutive of sinba, which the slaves used for senbora-was employed in addressing the daughter of the house. Iaiá (yaya) was the form of address for girls and young ladies generally. Mucama (mucamba) was the term for a favorite slave girl who served as housemaid, personal attendant, and cometimes as wet-nurse. (Translator.)

${ }^{60}$ Mäe.

${ }^{70}$ Demônio Familiar.

71 Tronco de lpê.

72 Sonbos de Ouro.

73 Pata de Gazela. José de Alencar was Brazil's great romantic novelist. He has been compared to Sir Walter Scott and to James Fenimore Cooper. (Translator.)

74 História de uma Moģa Rica.

75 Punição.

${ }^{76}$ Memórias de um Sargento de Milicias. Manuel de Almeida, who died prematurely, leaving this one masterpiece behind him, has been seen as a potential Brazilian Balzac cut off by death. (Translator.)

77 O Ateneu.

${ }^{78}$ A Carne.

${ }^{79} \mathrm{~A}$ vivacious account of practically all the writers mentioned by Freyre in this passage will be found in Erico Verissimo's Brazilian Literature: An Outline (New York, 1945). See the preface that Freyre wrote for the volume by Olivio Montenegro: $O$ Romance Brasileiro: As Suas Origens e Tendências (The Brazilian Novel: Its Origins and Tendencies) (Rio de Janeiro, 1938). (Translator.)

${ }^{80}$ Alfredo d'Escragnolle (Visconde de) Taunay is one of the best known and most mature of nineteenth-century Brazilian novelists. His novel Inocência is the most widely translated of Brazilian books. Among his collections of essays is Céos e Terras do Brasil (Heavens and Earths of Brazil) (Rio de Janeiro, 1882). Vieira Fazenda, Mello Moraes, and Mello Moraes fils were end-of-the-century publicists and memoir-writers. (Translator.) 


\section{Preface to the Second English-Language Edition liii}

ery, ${ }^{81}$ but none of them is of any great worth from the point of view of social history. As to the iconography of slavery and patriarchal life, that has been masterfully executed by artists of the order of Franz Post, Zacharias Wagner, Debret, Rugendas, not to speak of lesser and even untutored ones-draughtsmen, lithographers, engravers, watercolorists, and painters of ex-votos-who from the sixteenth century on (many of them being illustrators of travel books) have reproduced and preserved for us, with emotional power or realistic exactness, intimate household scenes, the life of the street, and the work of the fields, the plantations and manor houses, and ladies, slaves, and mestizos of various types. ${ }^{82}$ Out of the last fifty years of slavery there have come down to us, in addition to portraits in oil, daguerreotypes and photographs showing the aristocratic profiles of plantation-owners in their old-fashioned cravats; sinbá-donas and sinbá-mogas ${ }^{83}$ with little church-bonnets on their high-combed hair; young girls on the day of their first communion, all of them clad in white, with gloves, garland, veil, prayerbook, and rosary; and large patriarchal family groups, showing grandparents and grandchildren, young lads in the cassocks of seminary students, and small lasses smothered in the silks of full-grown ladies.

But I must not extend this preface any further, having already wandered sufficiently far afield from my original purpose, which was

${ }^{81}$ Among others, the novel by Adrien Delpech: Roman Brésilien, and Saint Martial's $A u$ Brésil; there is also Mme Julie Delafage-Brehier's book, Les Portugais d'Amérique (Souvenirs bistoriques de la Guerre du Brésil en 1635) (Paris, 1847). Senhor Agrippino Grieco, in a critical article upon this present work, recalls the novel written by the Spaniard, Juan Valera: Genio y Figura, "where there are scenes that have much to tell us about Rio in the middle of the Second Empire."

82 Among the albums may be mentioned: the Album Brésilien (aquatints) of Ludwig and Briggs on Rio de Janeiro and the Memória de Pernambuco (lithographs by F. H. Carls and drawings by L. Schlappriz). In addition, there are various collections of watercolors and engravings, among which may be noticed: the Oliveira Lima collection of Brasiliana at present in the Catholic Universiry of America, in Washington, D. C.; the collection of the old Baltar Museum, which, thanks to the happy initiative of its former director Estacio Coimbra, has been acquired by the $\mathrm{Mu}$ seum of the State of Pernambuco, under the direction of Annibal Fernandes; and the collections of the Historical Museum and the National Library in Rio de Janeiro. Also of historical interest are the ex-voto tablets scattered through the sacristies of old churches, plantation chapels, etc. Rotting away in the little church of Sitio da Capela, near Recife, are. some very interesting ones.

83 Terms applied to the ladies and young women of the Big House. (Translator.) 
merely to give a general idea of the plan and method of the essay that follows and the conditions under which it was written. An essay in genetic sociology and social history, with the object of determining and at times interpreting some of the more significant aspects of the formation of the Brazilian family. Unfortunately, I was not able to realize my intention of condensing the entire work into a single volume. The material overflowed, exceeding the reasonable limits of a one-volume book. The study of certain aspects of the subject accordingly had to be reserved for Volume II., and, for that matter, these could be developed still more extensively.

The turn-of-the-century period in Brazil, for example, remains to be interpreted-the attitudes, tendencies, and prejudices of the first generation to follow the Law of Free Birth ${ }^{84}$ and the debacle of $\mathrm{r} 888$; a study should be made of the anti-monarchist reactions of the propertied class, its bureaucratic inclinations, the tendency of many of its members to embark upon liberal careers by becoming State functionaries and obtaining republican sinecures-sinecures that prolonged the life of ease of the sons of ruined gentlemen and did away with the degrading necessity of engaging in manual labor for the sons of slaves anxious to put as great a distance as possible between themselves and the slave hut; in short, the entire bureaucratic and non-productive regime that, in the agrarian Brazil of old, with the exception of those regions that benefited more intensively from European immigration, followed the abolition of slave labor-all this should be related to slavery and to the one-crop system, which still continue to influence the conduct, ideas, attitudes, and sexual morality of Brazilians. So far as that is concerned, a latifundiary monoculture even after the abolition of slavery found a means of subsisting in certain parts of the country, with more absorptive and sterilizing effect than under the old regime and with abuses that were still more feudal in character, through the creation of a proletariat under conditions of life less favorable than those of the mass of slaves. Roy Nash was astonished to find in the hands of a single individual in Brazil landholdings that exceeded the whole of Portugal in size, while he learned that in the Amazon region the Costa Ferreiras were the owners of an estate whose area was greater than that of England, Scotland, and Ireland combined. ${ }^{85}$ In Pernambuco and Alagoas, along with the development of sugar factories, large-scale property has increased these last few

\footnotetext{
${ }^{84}$ Lei de Ventre Livre, passed in 1871, giving freedom to children born in slavery (although sometimes they

remained slaves until the age of twenty-one). (Translator.)

85 Roy Nash: The Conquest of Brazil (New York, I926).
} 


\section{Preface to the Second English-Language Edition Iv}

years, bringing with it in its wake, and as the result of monoculture, an irregularity and deficiency in the supply of foodstuffs such as meat, milk, eggs, and vegetables. In Pernambuco, in Alagoas, in Bahia, they continue to consume the same bad meat as in colonial days. Bad, and dear in price. ${ }^{86}$ It may be said, then, that from the point of view of the general welfare and that of the working classes in particular, the worst features of the old economic order persist, and have persisted since $\mathrm{r} 888$, when the patriarchal system was abolished that up to then had sheltered the slaves, fed them with a certain liberality, cared for them in sickness and old age, and provided their sons with an opportunity to rise in the social scale. The slave's place was taken by the pariah of the factory, the slave hut was replaced by the slums, and the plantation master by the factory-owner and absentee capitalist. Many Big Houses remained closed, with the big estate-owners roaming about in automobiles from city to city, living in Swiss chalets and Norman villas, and finding diversion in Paris with ladies of easy virtue.

I must express my thanks to all those who have aided me either in the work of research or in the preparation of the manuscript and reading of the proofs of this essay. In connection with the proofreading I am chiefly indebted to Manuel Bandeira. Another friend, Luis Jardim, has aided me in cleaning up the manuscript, which had left for Rio full of erasures and corrections. I wish to thank them

${ }^{86}$ According to official statisticsAnnuário Estatistico de Pernambuco (Statistical Yearbook of Pernambuco) (Recife, 1929-30)-the zone that in Pernambuco is sacrificed to monoculture embraces an area of $1,200,000$ hectares $[2,965,200$ acres $]$, with only 138,000 [340,998 acres] under cultivation. In an address delivered before the Rotary Club of Recife, Senhor André Bezerra, representing the Land-Lease and Cattle Corporation of that city, stressed the fact that 88.5 per cent of the zone in question was completely uncultivated, while 20 per cent of the total, or 240,000 hectares [593,040 acres], had been "transformed into pasture land, seeded with selected grasses and conveniently divided into enclosures, with adequate water supply, sanitary baths, etc., to maintain a herd of 240 ,ooo head, which, on the basis of ro per cent being utilizable for the purpose, would furnish 24,000 head for the slaughter pens. . .." (Diário de Pernambuco, April 2, 1933.) This is a subject that I propose to treat in greater detail in a forthcoming work. In passing I would remark that it is hard to understand the obstacles that are raised in Pernambuco to the importation of frozen meat from Rio Grande do Sul and São Paulo, which would improve the quality of foodstuffs and bring down the price, while at the same time no better use is made, from the point of view of the general welfare, of those lands that are sacrificed to a latifundiary monoculture unless it is that governments act the way they do under pressure from the so-called "silent interests." 
both for their intelligent assistance, as well as those who so kindly helped me in translating from the Latin, the German, and the Dutch passages in old documents, and those who facilitated my library and folklore research: my father, Dr. Alfredo Freyre; my cousin José Antônio Gonsalves de Mello (Neto); my friends Júlio de Albuquerque Bello and Sérgio Buarque de Hollanda; Maria Bernarda, who gave me a quite satisfactory schooling in culinary traditions; the former slaves and old plantation servants Luiz Mulatinho, Maria Curinga, Jovina, Bernarda. Sérgio Buarque translated from the German for me practically the entire essay of Wätjen. ${ }^{87}$ Júlio Bello on his Queimadas plantation brought together for me interesting folklore data concerning the relations of master and slave. Alone or in the company of Pedro Paranhos and Cicero Dias, I made excursions for folklore research, or for obtaining an acquaintance with the typical Big Houses, through various portions of the old aristocratic region of Pernambuco, and I must here thank all those who extended to me their hospitality on these occasions: Alfredo Machado on the Noruega plantation; André Dias de Arruda Falcão at Mupã; Gerôncio Dias de Arruda Falcão at Dois Leões; Júlio Bello at Queimadas; the Baronesa de Contendas at Contendas; Domingos de Albuquerque at Ipojuca; Edgar Domingues at Raiz-a true old people's home, where I encountered four survivors of the plantation senzalas, one of them a centenarian, the others octogenarians. The oldest of this group, Luiz Mulatinho, had a marvelous memory. In connection with other regions that I visited and which are now well known to me, I must recall the kindness of a number of persons: Joaquim Cavalcanti; Júlio Maranhão; Pedro Paranhos Ferreira, owner of Japaranduba, grandson of the Viscount and nephew of the Baron of Rio Branco; Estácio Coimbra; José Nunes da Cunha; the Lyra family in Alagoas; the Pessôa de Mello family in North Pernambuco; the relatives of my friend José Lins do Rego ${ }^{88}$ in South Paraíba; my own relatives, the Sousa e Mellos, on the São Severino dos Ramos plantation, in Pau d'Alho-the first plantation that I ever knew, which always awakens personal memories when I revisit it. My thanks to Paulo Prado, who

${ }^{87}$ E. Hermann Wätjen: "Das Judentum und die Anfänge der Modernen Kolonisation," in Das bolländiscbe Kolonialreich in Brasilien (Gotha, 1921). (Translator.)

88 José Lins do Rego, one of Brazil's most distinguished novelists, is the author of the "Sugar-Cane Cycle" (Ciclo da Cana de Assucar), a novel- sequence in which he describes, with a melancholy Thomas Hardy touch, the rapidly disappearing life of the old sugar plantations. Lins do Rego has also written one of the best essays on Gilberto Freyre, in his preface to Freyre's Region and Tradition (see note 5, above). (Translator.) 


\section{Preface to the Second English-Language Edition lvii}

arranged such an interesting excursion for me through the old slaveholding region that extends from the state of Rio to São Paulo, offering me hospitality afterwards, he and Luiz Prado, at the coffee plantation of São Martinho. I wish to thank him also for his advice to return from São Paulo to Rio by sea, in a small steamer putting in at the old colonial ports, a bit of advice that Capistrano de Abreu used to give my friend. The author of the Portrait of Brazil, ${ }^{80}$ the truth is, distrustful and fond of his ease, never put into practice the old caboclo's advice, possibly because he foresaw the horrors to which those innocent ones who entrusted themselves to boats of the Irati make would be subjected in their laborious effort to become acquainted with this portion of our Brazilian physiognomy, which is such an expressive one.

I must extend my thanks, also, for the courteous treatment shown me in libraries, archives, and museums in the course of my researches: at the National Library of Lisbon; at the Portuguese Ethnological Museum, organized and directed by the scholarly Leite de Vasconcellos; at the Library of Congress in Washington, especially in the documents section; at the Catholic University of America, whose Oliveira Lima Collection is so rich in rare travel books on Portuguese America; at Stanford University, whose John Casper Branner Collection similarly specializes in books on Brazil by foreign scientistsscientists who, like Saint-Hilaire, Koster, Maria Graham, Spix, Martius, Gardner, Mawe, and Prince Maximilian, were often keen observers of the social and family life of Brazilians; in the documentary section of the Stanford Library, where I made use of the valuable collection of diplomatic reports and British parliamentary documents ${ }^{80}$ on the life of slaves on Brazilian plantations; at the National Library of Rio de Janeiro, at present directed by my friend and teacher Rudolfo Garcia; at the library of the Brazilian Historical Institute, where I was always so graciously received by Max Fleiuss; at the Archæological Institute of Pernambuco; at the Nina Rodrigues Museum in Bahia; in the documentary section of the Library of the State of Pernambuco; at the Registry Office of Ipojuca, whose nineteenth-century inventoriès afford interesting documentation for the study of the old slave-holding economy and patriarchal family

${ }^{89}$ The Retrato do Brasil is a famous work by Paulo Prado. Capistrano de Abreu, the "old caboclo," fine scholar and historian of the turn-of-the-century era, was an authority on Indian dialects. (Translator.)
${ }^{90}$ British and Foreign State Papers, 1825-1841 (London); and Parliamentary Papers (London), especially, Reports from Committees, Sugar and Coffee Planting, House of Commons. Session $1847-8$. 
life; and, finally, at the Cathedral of Olinda, whose archives contain the manuscripts of pastoral letters and bishops' reports touching on fashions, sexual morality, the relations of master and slave, etc.manuscripts which the canon, Carmo Baratta, kindly placed at my disposal for purposes of study. I thank my good friends André and Gerôncio Dias de Arruda Falcão and Alfredo Machado for having thrown open to me their family archives at the Noruega plantation, with virgin documents dating from the time of Commander Manoel Thomé de Jesus, while others are of the epoch of the Baron of Jundiá -some of these are of lively interest for the study of the social life of plantation-owners and their relations with their slaves. To José Maria Carneiro de Albuquerque e Mello, director of the Library of the State of Pernambuco, my thanks for the excellent reproductions from Piso, Barleus, and Henderson, which at my request were prepared for use as illustrations, in this book. Thanks also to Cicero Dias and to the architect Carlos Pacheco Leão for plans of the Big House of Noruega. There is one other name that must be associated with this essay: that of my friend Rodrigo M. F. de Andrade. $\mathrm{He}$ it was who chiefly inspired me to write and publish it.

I am not unaware of those defects of construction in this essay which various critics have emphasized. Some of these I have undertaken to correct, but there remains throughout this book that lack of cohesion of subject-matter which a foreign critic, even though a most friendly one, has taken occasion to lament in connection with these pages, which have in them so little that is French in their technique and, it may be, little that is Latin in their manner of presentation, which is somewhat loose and informal. It should be remarked, however, that this essay pretends to be not so much a conventional literary work as a piece of research and an attempt at a fresh interpretation of a determined group of facts having to do with the formation of Brazilian society.

With regard to the method of interpreting my material, I have endeavored to be almost entirely objective, but at certain points an objective-introspective method has been employed, somewhat in the manner of certain Spanish studies in which there is to be seen an extension of the technique of introspective analysis to the task of recapturing the past and the life of a people-the concentration of the Spiritual Exercises applied to the more intimate facts of history until one is able to feel the life lived by our ancestors in all its, so to speak, sensual fullness of outline. It is also the Proustian method extended to social history after having been Romain Rolland's technique of mak- 


\section{Preface to the Second English-Language Edition lix}

ing his characters lose their present-day identity in the successive "several times" of their forefathers. Jean-Christophe, as readers of Rolland will recall, sometimes felt that what was now was not now, but some other time. There seems to be no social history when the past is not re-captured in this way until it becomes as alive as the present and the present seems to be some other time of the re-captured past.

It is said of Michelet that he tried to re-capture the past of medieval France by re-peopling its great churches: through architecture. It seems that in the Brazilian past, as in some other pasts, the equivalent of great churches or castles or kings' palaces was the big patriarchal houses that were at the center of the community's life during its formative years. To re-capture that life, one has to attempt to repeople those houses. And no attempt of this sort can be valid without what some modern historians know as "imaginative sympathy." That is why one modern historian, following suggestions from Herder, has said that "we ourselves are Time, inasmuch as we live."

With this notion of Time the past ceases to be dead in contrast with the present as the only living reality. Historical periods are now considered by some students of man to be as valid for a genuine division of mankind as races and nations-rather than societies and cultures that sociologically do not seem ever to die entirely, but appear to combine in new forms.

As to the absence of didactic qualities in this book, stressed by one critic, I am fully aware of it; but the truth is that I have no pedagogic intention. Similarly, my purpose is not to draw conclusions, much less to judge. Taking as my point of departure new hypotheses, ideas, and even at times highly personal intuitions, I have limited myself to the effort to determine certain aspects of the patriarchal influence in the formation of the Brazilian family, though I do at times venture upon interpretations of this influence on present-day Brazil. To those thinkers who are wholly uninterested in historical and sociological research I leave the task, a loftier and more brilliant one, to be sure, of formulating conclusions independent of historical research. What will be found here is simply a group of facts that, by reason of their constant social significance and the novel manner in which they are presented and interpreted, may possibly give pause for thought in a direction contrary to the opinions advanced by those improvisers who are not always very exact in the conclusions they reach through a process of pure sociological divination. I have attempted a study of Brazilian patriarchal society and culture in which the social reality is 
seen as a constant flow of the past and the present into the future-a constant flow of time that never stops to allow for definitive sociological conclusions about rigid "historical periods."

Still other critics have noted that there are few references in this work to the great names among the historians of my country-Handelmann, for example, Southey, Varnhagen, Capistrano, Oliveira Lima, Rocha Pombo, João Ribeiro, Joaquim Nabuco, some of whom have written memorable pages on the subjects treated here-slavery, for instance. ${ }^{91}$ This apparent lack of devotion to the masters on the part of a beginner is partly to be explained by the fact that one of my chief concerns has been a direct contact with my sources, so often cited in these pages: the manuscripts to be found in family archives and churches; the letters of the Jesuits; wills; allotments; diaries; travel books written by foreigners; royal decrees and regulations; the correspondence of colonial governors with the court; newspapers; pastoral letters; doctoral theses; physicians' reports; acts in chamber; etc. It is upon such material as this and upon researches made in the field that this essay is in reality based, and not upon the books of recognized historians and their use and interpretation of those sources.

It would be impossible to reply here to those who have criticized the language of this essay-a language that represents a reaction, possibly exaggerated, to the pedantries of scientific erudition, technical terminology, grammatical correctness, and style. By a critic more orthodox in his notions of propriety I have been accused of being "anecdotical," while my language is "lacking in dignity" for "so serious a work"-it is even "vulgar" and "anything but technical."

With respect to the last point, I would merely remind my readers

$91 \mathrm{H}$. Handelmann is the author of a history of Brazil, translated from the German and published in Portuguese (História do Brasil) at Rio de Janeiro in 1931. Robert Southey's History of Brazil (London, 1810-19) is well known. The nineteenth-century historian Adolpho de Varnhagen wrote an História Geral do Brasil (General History of Brazil), an História das luctas contra os bollandezes (History of the Struggles against the Dutcb), an História da Independencia (History of Independence), etc. Capistrano de Abreu's works include: Brasil no seculo XVI (Brazil in the
Sixteenth Century); $O$ Descobrimento do Brasil (The Discovery of Brazil); and Capitulos de bistória colonial (Cbapters of Colonial History). Oliveira Lima's Memórias (Memoirs) appeared at Rio de Janeiro in 1937; there are many passages in his earlier writings dealing with $\mathrm{Bra}$ zilian history. He was a statesman, diplomat, and historian. Rocha Pombo is the author of an História do Brasil, as is João Ribeiro. Joaquim Nabuco is the author of several historical essays, one of them-O Abolicionismo (London, 1883)-on the abolition movement. (Translator.) 


\section{Preface to the Second English-Language Edition lxi}

that in sociological, anthropological, and historical-social studies the criterion of the worth of facts is every day coming more and more to take its place alongside the criterion of pure materiality, tending to break the rigidity of the latter, to humanize it. In connection with such studies the time is past for imitating that difficult and inhuman idiom in which certain scientists, chiefly technicians, take a delight. This for the very reason that the situation in the social sciences is different from that in the other sciences. As MacIver says, in his great sociological work, Community, ${ }^{92}$ there are no chemically good or evil results and combinations, just as there are no geologically good or evil types of rocks. For the student of the social sciences, on the other hand, things-even the most elementary of things-in their relations with societies undergo a prolongation into values and are good or bad, rich or poor, depending upon the human interests involved. To deprive sociology of this human aspect would be to deform it; and all this, to quote MacIver's works, "in a vain attempt to ape the socalled natural sciences."

The sociological, anthropological, and historical-social essay has a language of its own; it is not obliged to limit itself to an exact terminology as conceived by other sciences that are not concerned with human values. Its language may at times resemble the language of the novel or the literary essay.

I do not know how to answer, without the risk of appearing pedantic, all the misrepresentations of my points of view by literary critics and journalists, of the "Right" as of the "Left," who possess as yet little familiarity with the technique, method, and terminology of genetic sociology and social history, anthropology, and social psychology. This terminology has been employed only when strictly necessary. I have preferred to address myself to the intelligent reader rather than to the initiate. It is to be hoped, however, that with the progress of instruction in these branches in my country-the University of Brazil and the universities of São Paulo, Bahia, Recife, Porto Alegre, and Minas Gerais are hastening such progress-those critics who are none too familiar with the sociological meaning of such expressions as "culture," "complex" (sociological or anthropological), "social mobility," and "genetic sociology" will acquire a little scientific humility in their criticisms. In the case of some, one wishes this for the sake of their own intellectual and personal reputations; in the case of others, for the sake, also, of the ideologies that they so emphatically defend. There is no doubt that, with the

92 R. C. MacIver: Community, A Sociological Study (New York, 1928). 


\section{lxii}

progress of such instruction, the idea will soon disappear in Brazil that sociological or anthropological culture-as necessary for creative works as it is essential for critical studies-is something that can readily be improvised.

There have been, meanwhile, not a few intelligent criticisms, among them the painstaking and penetrating analysis by Professor Almir de Andrade-and also certain suggestions technically well considered, some of which were embodied in the second editioncriticisms and suggestions that the author of Casa-Grande \& Senzala has received not only from foreign specialists, but also from scholars at home, and which are always to be expected in the case of a work as daring as this, accomplished in so short a time, a work that undertakes to reconstruct and interpret the most intimate aspects of our nation's past while endeavoring to probe the racial and, above all, the cultural antecedents of Brazilian society, so profoundly agrarian-patriarchal in its formation. The truth of the matter is: a degree of boldness, above all else, was required for the undertaking of so complex a task; and boldness at times may have a renovating and even creative effect, but at the cost of numerous imperfections and deficiencies such as are wholly avoided by only the most captious of historical and scientific miniaturists.

Certain criticisms, even among the most authoritative ones, the author has received as the differing and eminently to be respected opinions of specialists and masters, without for that reason feeling obliged to modify his own points of view. This may be said of the observations of Professor Coornaert of the Sorbonne and of Professor Martin of Stanford-in articles otherwise very friendly to the author-regarding what they considered an excessive preoccupation with the sexual elements in the interpretation of some of the most characteristic aspects of our social evolution. But these criticisms appeared before the publication in the English language of the now famous Kinsey Reports. Then there were the reservations of Professor Sylvio Rabello-one of the ablest of our specialists in the field of pedagogy and social psychology-with respect to the excessive importance attributed to the formative influence of environment upon the Brazilian living within a patriarchal slave-holding economy.

Some of the most substantial criticisms of Casa-Grande of Senzala came from an old-time conscientious investigator of the indigenous cultures of northern Brazil: Carlos Estevão de Oliveira, for some time director of the Goeldi Museum, who devoted to the second edition of this book a long, minute, and at the same time extremely sympathetic analysis from the point of view of his favorite studies. 


\section{Preface to the Second English-Language Edition Ixiii}

According to this scholar, the masculine sex among Brazilian Indians-at least, among the tribes of his acquaintance-has not perceptibly diminished as a result of agricultural labor, which with them is woman's specialty. But it is possible that the tribes known and studied by Senhor Estevão de Oliveira over a period of twenty years had been directly or indirectly influenced by European colonization and by European patterns of the sexual division of labor. As to the interpretation that he suggests, of "sympathetic magic applied to the sowing of grain," it impresses me as one of the most lucid to have been advanced, there being, moreover, no discrepancy between it and those patterns of the sexual division of labor which, according to some of the best students of the subject, were followed by the natives of Brazil at the time the Portuguese arrived.

Worthy of consideration also is a suggestion from the same source that the "list of fruit trees cultivated [by the natives of Brazil, that is to say] and handed down to us" should include "the guava tree, the pupunha tree, ${ }^{93}$ the genip tree, ${ }^{94}$ the cacao, and the cashew." The areas dominated or influenced by these cultures should be determined as soon as possible in order that the sociologist or social historian may be able to make use of such data in interpreting and reconstructing those facts having to do with the formation of Brazilian society which have been most affected by the influence of American Indian culture on that of the foreign-comers, and particularly the influence exerted upon the culture of the Portuguese colonists who set up their patriarchal regime in Brazil as large-scale agriculturists. It is these latter who are the object of study in Casa-Grande \& Senzala; for to this writer, in his work, about the only elements of interest in connection with the indigenous and Negro cultures were those absorbed by the type of agrarian-patriarchal colonization that is represented economically, in the first two centuries of Brazilian life, by the sugar plantation and socially by the Big House and the slave hut.

As to the other objections of Carlos Estevaào de Oliveira-such as what he has to say with regard to the interpretation of the form of family organization among the aborigines of Brazil, the position of woman, that of bisexuals, the possible stimuli resulting from the seg-

${ }^{93}$ The pupunbeira, a tall prickly palm of the genus Guilielma (Guilielma speciosa Mart.), also known as pupunba verde-amarela (greenishyellow pupunba), the pupunba being the fruit of the pupunbeira). (Translator.)

94 The jenipapeiro, a tree of the
Rubiacea family (Gen. americana Lin.). The tree is known in English as genip (or genip tree), its fruit as genipap. The fruit is "the size of an orange, oval, with greenish-white rind, dark purple-blue juice, and a somewhat acrid flavor."-Standard Dictionary. (Translator.) 
regation of men for homosexual practices, the significance of urucú painting, ${ }^{95}$ and the like-some of these have to do with controverted questions of cultural anthropology which still are in flux, while others involve the variations to be found between tribes, variations which, from the point of view of the influence of the more or less general traces of native culture upon the formation of an agrarian-patriarchal society in Brazil, render it difficult to separate the representative or typical from the exceptional case, the exceptional being often assimilated in place of the typical. To undertake to resolve these points would have meant a possibly endless discussion between critic and author, in which, it is obvious, the former would always have had the advantage of his direct, living knowledge of the present specialized forms of indigenous culture in northern Brazil. The late director of the Goeldi Museum, it seems to me, was under the obligation to treat this subject in an essay, one that would have been looked forward to with interest, not to say impatience, by those who knew him well and knew how assured and accurate a knowledge he possessed of Brazilian ethnography. Unfortunately, he died without having written such an essay.

Another critic raised another controversial question. This had to do with the extension of communism - that is to say, of communism sociologically considered-among American societies. There appears to be no doubt that there was a greater tendency in that direction than toward individualism, though a fondness for private property was not foreign to certain groups, and under forms that at times are surprising. This inclination, however, was never strong enough to lead them to adapt themselves readily or immediately to the European concept of private ownership.

A subject that is treated in Casa-Grande \& Senzala and which Carlos Estevão de Oliveira courageously attacks in the course of his patient analysis is the "clash of European with native culture" and "the effects of the Jesuit catechism upon the Brazilian tribes." Carlos Estevão recognizes the considerable importance of this problem: "Had the study embraced only these two themes, the author would have given us a worth-while work, in view of the fact that, at least so far as I am aware, no one to this day has analyzed them so photographically." For the illustrious student of Brazil's native culture, or, better, cultures, "the conquistadores . . . and the Jesuits" were in

95 The urucú or (in English) arnotto is a small tropical American dye-yielding tree of the Bixaces or Indian plum family (Bixa orellana).
It produces the annatto of commerce. The Indians used it extensively for dyeing purposes and body decorarion. (Translator.) 


\section{Preface to the Second English-Language Edition $\mathbf{l x v}$}

fact "the initiators of its decadence" (that is, the decadence of those cultures). This is a fact that I emphasized without meaning to assert thereby that the Amerindian societies should have been idyllically preserved from all Europeanization and, much less, all Christianization. The methods of Europeanization employed by the sugarplanters and the bandeirantes and the methods of Christianization used by the Jesuits were not always the most intelligent, the most Christian, or the most humane ones. This is true, at least, from the point of view of the better use that might have been made of the native peoples and their culture in the formation of Brazilian society. Brazil owes much to the Jesuits, some of whom are heroic figures who will always be associated with the difficult beginnings of civilization in the tropical region of the Americas, a fact that has been proclaimed by some of the major voices in our literature: by Joaquim Nabuco, by Eduardo Prado, by Oliveira Lima, by Capistrano himself, who was so hard to please in his enthusiasms. It is simply that we must have the courage not to be content with a unilateral and piously conventional interpretation of Brazil's past, for the voluptuous use of apologists for the missionary work of the Society of Jesus. It would be banal to repeat here that the life of any institution is full of ups and downs, while none has a past that is altogether glorious. ${ }^{96}$

It is precisely this aspect of the analysis that I made, or undertook to make, of the work of the Jesuits in Brazil, in one of the chapters of Casa-Grande \& Senzala, which forms the subject of a paper by Father J. Alves Correia, a venerable Portuguese missionary who has made a special study of the activities and contemporary tendencies of various Catholic missions conducted by his countrymen. In his paper, Father Alves Correia agrees with the criticism made by the present writer of the "exaggerated academicism in the education of the native" by the Jesuits; and this leads the erudite historian Father Serafim Leite of the Society of Jesus, also a Portuguese, to take up the cudgels in an article published in the review Broteria. According to Father Leite, the author of Casa-Grande of Senzala is an enemy not only of the Society, but, as it appears, of the Church itself: an enemy "cloaked in Casa-Grande of Senzala and ... unmasked in Sobrados e Mucam-

${ }^{96}$ Euclides da Cunha, in his famous work Os Sertōes (published in English as Rebellion in the Backlands, University of Chicago Press, I944), similarly wrestled with the problem of the Jesuits; and it may be of interest to compare Freyre's remarks on this subject in his essay Atualidade de Euclides da Cumba (Contemporaneity of Euclides da Cunba) (Rio de Janeiro, 1941). Freyre speaks of Da Cunha's ultimate "reconciliation". with the Jesuits-it would be better to say with Jesuit history in Brazilthrough his admiration for the lyric figure of Anchieta. (Translator.) 
bos." ${ }^{97}$ In this the scholarly cleric, ordinarily so unperturbed, was being a bit extreme. It was Father Alves Correia who felt obliged to defend the author against the charge of sectarianism, of being prejudiced against the Catholic clergy in general and the Society of Jesus in particular. He wrote that "so far as sectarianism is concerned," it would take "a magnifying glass to discover it" in the descriptions contained in these two essays-descriptions that he has the kindness to describe as "taken from the life"-of the "methods employed by the Jesuits in their schools." "To tell the truth," he says, "we do not find that Gilberto Freyre is an enemy of the Society of Jesus. He could have been more of an enemy than he is; or he could [on the other hand] have been a fervent admirer [of the Society], blind to or worshipping its defects, which are those of an era rather than of the Jesuit pedagogues themselves." Meanwhile, Father Serafim's words aroused an echo in Brazil among the members of the Jesuit right wing of Catholicism, one of whom demanded for Casa-Grande o Senzala the extreme punishment of auto-da-fe, insisting that both the book and its author be burned. Nor did he mean burned in effigy or in oil portrait; he was employing the word in the most realistic sense, an attitude that has not met with the approval of the Jesuits of Etudes (Paris), so generous in their treatment of the French translation of this book.

A word as to the criticism made of this book, among extremely courteous references to its author, by the eminent scholar in the field of historical research in our country, Professor Affonso d'E. Taunay: to the effect that it is concerned almost exclusively with the northeast and neglects the social landscape of the south. But this essay, as it happens, is one that deals with genetic sociology rather than with history in the conventional sense-though it frequently has recourse to historical chronology and even to anecdotal history-and the author's task accordingly has been to make a study of the patriarchal system based upon a latifundiary and slave-holding monoculture in that part of the country where the system found its most characteristic and forceful expression. Only in the eighteenth century-which is studied sociologically, in some of its aspects, in Sobrados e Mucambos-does the patriarchal family regime attain some prominence in the Minas region, a prominence diminished by the greater power of the crown there and by the influence of the Minas cities, more autonomous than those in the north. As for Rio de Janeiro, it was, one might say, an exceptional blot-a northeastern blot-upon the south-

97 Freyre's Sobrados e Mucambos (São Paulo, 1936) is the sequel to the present work, The title means "town houses and slums." It will shortly appear in English, French, Italian, and Spanish. 


\section{Preface to the Second English-Language Edition lxvii}

ern landscape; for in São Paulo and other portions of the south it is an exception to find large-scale property and monoculture developing to any extent.

To be sure, in nineteenth-century São Paulo the agrarian-patriarchal regime was to be revived in a new form, that of a slave-holding monoculture based not upon sugar, but upon coffee, which, along with the advantages offered by the climate, was to permit the development of immigration to that province from Italy and other European countries, thereby stimulating various tendencies to social transition in Brazilian life, including that trend toward a republic which was so marked among Paulistas of the second half of the nineteenth century. But these more recent aspects of the disorganization of the colonial patriarchal system in Brazil and of the organization in a certain more accentuatedly national direction of economic and family life in our country are precisely the subject of a study in the next and final essay of the series begun with Casa-Grande \& Senzala, to be entitled Ordem e Progresso.98

A word, also, to the Portuguese journalist who felt a trifle offended by the comparison, in Casa-Grande \& Senzala, of the figure of the Lusitanian colonist-whom the author greatly admired-with the $\mathrm{Ne}$ gro, the point being that the latter should rather have been included among the purely physical elements and resources that contributed to the agrarian organization of Brazil-such as horses, oxen, beasts of burden. The observation is an interesting one. It happens, however, that in sociology and cultural anthropology it is customary to separate man from the animals by the capacity peculiar to man (or, at any rate, enormously greater in man) of becoming a creator of culture. Upon the basis of this criterion-an erroneous one, if you will-it is necessary to include the Negro with the human element. The author does not feel that he is invested with the authority or possessed of the boldness requisite to undertaking to revolutionize the social sciences in so important a respect as this.

In collecting the data for this book I did not follow a rigorously geographical or historical criterion, though I was always faithful to the regional one based upon the area in which the historical-social formation of Brazilian society sociologically began, with its greatest vigor: the Northeast. Within this criterion-which is at once genetic and regional-I could not fail to give prominence, at times great prominence, to sugar and, as a consequence, to northeastern group-

${ }^{08}$ Ordem e Progresso (Order and Progress) is the national motto of Brazil. (Translator.) 
ings in the development of the patriarchal (agrarian and slaveholding) family in our country. The influence of this technique of production and of the societies that developed on the basis of it-in Maranhão, Bahia, Pernambuco, and Rio de Janeiro-was so strong that for a long period sugar gave to Brazilian society, taken as a whole and seen simply for what it was, its most characteristic traits, by creating the conditions most favorable to economic and social stability and organized family life. It was the two economies, sugar and coffee, that conditioned the development of our agrarianpatriarchal system, at least in its essential features; and I believe that no serious study of the formation of Brazilian social life can be separated from that system, for it is under its influence or in opposition to it that the formation is to be perceived taking place. Such was the case with the bandeirante movement, with which, possibly, may be associated the formation, not alone of a society based upon the exploitation of gold-in Minas Gerais-but of pastoral groupings that to this day are antagonistic, in their interests, their style of living, and their culture, to those groups of purely agrarian origin whose interests were for so long a time economically and politically dominant in Brazil. Whence the Brazilian-and not merely the Pernambucan, Bahian, or northeastern-character of interpretations based upon material gathered in those centers where an agrarian and patriarchal society took shape. Gathered in those centers, to be sure, but without any geographic exclusiveness and indifference to the marginal areas or to those areas antagonistic to the sugar and coffee zones: the pastoral, the diversified farming, and mining regions. The trips that I made for purposes of study and observation through those areas of Brazil which are less agrarian in background than the northeast-being wholly pastoral or semi-industrialized, as are certain neo-Brazilian areas in the southern part of the country-have merely confirmed me in the ideas and interpretations outlined in this book. The subject is one that I propose to treat in greater detail in Ordem e Progresso.

This book continues to call forth contradictory criticisms. "He reaches no conclusions," some say, repeating the word of the great scholar João Ribeiro. "He draws too many conclusions," others say. Senhor Miguel Reale finds the work cold and, so to speak, lacking in soul; but a foreign critic, while making use (without indicating its source) of the historical-sociological material presented by me, terms the book "emotional" and "impassioned." Even if I were more optimistic than I am with regard to my own efforts, I still would be content with the fact that this book had aroused mental and sentimental reactions so diverse in kind. I am also pleased with the fact that docu- 


\section{Preface to the Second English-Language Edition lxix}

ments recently published in Brazil furnish new evidence in favor of my suggestions. These documents confirm the sociological fact that the Big House complex, considered in its architectonic expression-so significant from the historical and social point of view-presents essentially the same aspect in the oldest agrarian regions of Brazil, whether northern or southern. Diversities of a topographical nature or those caused by regional climatic conditions do not alter it with respect to the essential human or social ecology involved. The complex has its peculiarities in the south and center of the country, and these call for special study; but everything goes to indicate that the sociological process operates in practically the same manner as in the north in those areas which are less intensely agrarian and latifundiary -the intensity having reference now to the time factor, now to the spatial one, and again to both.

Keeping my distance from a so-called ethnic determinism, I continue to incline toward a cultural and historical interpretation of the facts having to do with the social formation of a people as the one best corresponding to the complexity of the facts themselves. But a cultural interpretation completed by the psychological and, in some cases, by the functional one, without any rigidly exclusive tendency to substitute a cultural for a racial determinism.

Preceding recent books published in English, this book - written in Portuguese, and published in Rio de Janeiro as long ago as 1933-has been, since its appearance, a modest pioneer attempt to add to a socialhistorical approach to the study of the past-present of a halfEuropean, half-primitive society and culture a multi-anthropological approach: sociological, cultural, functional, ecological, and psychological. So psychological that sometimes it is less the strictly psychological approach of academic psychologists than that of novelists who have found it necessary to add a psychological time to the conventional chronological one, in novels otherwise historical in their substance-as in Balzac's analysis of French bourgeois society-and ultra-historical or intra-historical only in form or dimension-as in some of Unamuno's interpretations, through a partly fictional literature, of Spanish life and character.

Perhaps it may be admitted, in a study like this one, where the chronologically historical approach had to be completed by the sociological-anthropological one, that a psychological time is sometimes to be made the predominant one for the more vivid presentation of relations among events and among human beings artificially separated by conventional historical time. For the sociological interpretation of the Brazilian social past it means little, almost nothing, that in 
$\mathrm{lxx}$

1822 Brazil ceased to be a colony in the purely political sense. Other political changes, so prominent in chronological history, are insignificant from the same point of view. Hence the greater importance given to a sort of psychological-sociological time.

For the Brazilian past here sought for has been almost exclusively the past that the French call bistoire intime and the Spaniards sometimes describe as intra-bistoria. When the Goncourts wrote of an bistoire intime that it was a roman vrai and would eventually become la vraie bistoire bumaine, they had a vision of a modern development in both history and literature.

Gilberto Freyre

Lisbon-Stratford-Berlin-Rio de Janeiro-Recife 1933-1955 